\title{
Intraperitoneal Route of Drug Administration: Should it Be Used in Experimental Animal Studies?
}

\author{
Abdullah Al Shoyaib ' • Sabrina Rahman Archie ${ }^{2}$ • Vardan T. Karamyan 1,3 (D)
}

Received: 8 January 2019 / Accepted: 27 November 2019 / Published online: 23 December 2019

(C) Springer Science+Business Media, LLC, part of Springer Nature 2019

\begin{abstract}
Intraperitoneal (IP) route of drug administration in laboratory animals is a common practice in many in vivo studies of disease models. While this route is an easy to master, quick, suitable for chronic treatments and with low impact of stress on laboratory rodents, there is a common concern that it may not be an acceptable route for drug administration in experimental studies. The latter is likely due to sparsity of information regarding pharmacokinetics of pharmacological agents and the mechanisms through which agents get systemic exposure after IP administration. In this review, we summarize the main mechanisms involved in bioavailability of IP administered drugs and provide examples of pharmacokinetic profiles for small and large molecules in comparison to other routes of administration. We conclude with a notion that IP administration of drugs in experimental studies involving rodents is a justifiable route for pharmacological and proof-of-concept studies where the goal is to evaluate the effect(s) of target engagement rather than properties of a drug formulation and/or its pharmacokinetics for clinical translation.
\end{abstract}

KEY WORDS biopharmaceutical · intraperitoneal · macromolecule · pharmacokinetics · small molecule

Vardan T. Karamyan

vardan.karamyan@ttuhsc.edu

Department of Pharmaceutical Sciences, School of Pharmacy TTUHSC, Amarillo, Texas, USA

2 Department of Pharmaceutical Technology, Faculty of Pharmacy University of Dhaka, Dhaka, Bangladesh

3 Center for Blood Brain Barrier Research, School of Pharmacy TTUHSC, 1300 Coulter St., Amarillo, Texas 79106, USA

\section{INTRODUCTION}

It is well-recognized that the route of administration is a critical determinant of the final pharmacokinetics, pharmacodynamics as well as toxicity of pharmacological agents (1). Intravenous (IV), subcutaneous (SC), intraperitoneal (IP) and oral routes are the main paths of drug administration in laboratory animals, with each offering advantages and disadvantages depending on specific goal(s) of the study. One of the more commonly used routes in rodent studies is the IP route where a pharmacological agent is injected into peritoneal cavity. This easy to master technique is quick and minimally stressful for animals. It involves holding of the rodent in a supine position with its head tilted lower than the posterior part of the body and insertion of the needle in the lower quadrant of the abdomen (at $\sim 10^{\circ}$ angle) with care to avoid accidental penetration of the viscera (2-4). Large volumes of solution (up to $10 \mathrm{ml} / \mathrm{kg}$ ) can be safely administered to rodents through this route (5) which may be advantageous for agents with poor solubility. This route is especially common in chronic studies involving mice for which repetitive IV access is challenging. In most cases, IP administration is also preferred over the oral route for biological agents to avoid the GI tract and potential degradation/modification of biopharmaceuticals. The main disadvantage of this route is that it is minimally used in clinic (mostly for treatment of peritoneal cancers), because of which its use in experimental studies is often questioned and discouraged. To mitigate this concern, in this review article we discuss the anatomy and physiology of the peritoneal cavity, and the mechanisms governing absorption of substances from peritoneal cavity. In addition, we provide examples and compare pharmacokinetic profiles of small and large molecules upon IP and other routes of administration in experimental animals. Based on the discussed experimental evidence, we conclude that IP administration of drugs in experimental animals is a justifiable route for pharmacological and proof-of-concept studies where the goal is to evaluate the 
effect(s) of target engagement rather than properties of a drug formulation and/or its pharmacokinetics for clinical translation.

\section{ANATOMY AND PHYSIOLOGY OF PERITONEAL CAVITY}

Peritoneal cavity is a closed space within the abdomen that contains the abdominal organs and is derived from the coelomic cavity of the embryo. Peritoneal cavity is lined by the most extensive serous membrane in the body (i.e., peritoneum) which has total surface area equaling to that of the skin surface (6). Peritoneal cavity is filled with a thin film of fluid (peritoneal fluid) comprised of water, electrolytes, proteins, cells and other substances originating from the interstitial fluid of the adjacent tissues. In humans, the volume of peritoneal fluid ranges from 50 to $75 \mathrm{ml}(7)$, whereas in mice its volume ranges between 0.02 and $0.1 \mathrm{ml}(8)$. In addition, the peritoneal fluid contains leukocytes and antibodies to fight off infections, and plasma proteins at concentration that is about $50 \%$ of what is found in plasma (9).

Peritoneum covers most of the intra-abdomenal organs and consists of a single layer of squamous mesothelial cells (10). The mesothelial cell layer sits on a thin basement membrane and the majority of these mesothelial cells are flattered type with an approximate diameter of $25 \mu \mathrm{m}$. Mesothelial cells are closely connected to each other by either tight junctions, adherens junctions, gap junctions or desmosomes (11). The sub-mesothelial layer of peritoneum contains collagen, adipose tissue, lymphocytes, blood vessels as well as lymphatics (12). Fibroblasts and occasional macrophages are also present in this part of the peritoneum (13). Notably, the apical surface of mesothelial cells contain microvilli of different length, shape and density, which increase the functional surface area of the peritoneum (Fig. 1) (14).

Peritoneal mesothelial cells play crucial role in maintenance of peritoneal homeostasis and transport of fluids and solutes across the membrane. Intra-abdominal organs and mesentery are supported by the visceral peritoneum, whereas the parietal peritoneum lines up the abdominal wall, pelvis, anterior surfaces of retroperitoneal organs, and inferior surface of the diaphragm. The peritoneum minimizes friction and facilitates free movement between abdominal viscera, resists or localizes infection, and stores fat, especially in the greater omentum $(15,16)$. Importantly, the peritoneal mesothelial cells possess many features of epithelial cells including presence of polygonal, cobblestone morphology with surface microvilli and an ability to form a polarized monolayer that permits unidirectional transport of molecules (17). The peritoneal fluid has a $\mathrm{pH}$ of 7.5-8.0 and buffering capacity (18), because of which substances are rarely ionized in the peritoneal cavity after IP administration (19).

\section{PERITONEAL BLOOD FLOW}

The sub-mesothelial layer of the peritoneum supports a complex but efficient vascular network of blood and lymphatic vessels $(20,21)$. Most of the circulatory vessels are blood capillaries but few arterioles and venules are also present in the submesothelium (22). The density of these sub-mesothelial microvessels varies along different portions of the peritoneal cavity. For example, in the rabbit, the most vascularized area of peritoneal cavity is mesentery, which contains about $71 \%$ of peritoneal microvessels, whereas the diaphragm and parietal peritoneum contain about $18 \%$ and $11 \%$ of microvessels, respectively $(21,23)$. Through these capillaries, peritoneal cavity receives 4 to $7 \%$ of the total cardiac output in the rabbit (24) and rat $(25,26)$. The average peritoneal blood flow rate in the rat is $2.5-6.2 \mathrm{ml} / \mathrm{min} / \mathrm{kg}$ (24). Notably, blood supply to visceral peritoneum and intra-peritoneal organs originates from the coeliac, superior and inferior mesenteric arteries, whereas the parietal peritoneum is irrigated form the branches of circumflex, iliac, lumbar, intercostal and epigastric arteries $(27,28)$. Similarly, the venous system that drains from the visceral peritoneum empties into portal vein, whereas the veins that drain from the parietal peritoneum empty into the inferior vena cava $(28,29)$. Overall the entire peritoneum is well perfused with blood capillaries and provides an excellent surface for exchange of drugs between the peritoneal cavity and plasma (24).

\section{PERITONEAL LYMPHATIC SYSTEM}

Like many other organs, peritoneum has a well-structured lymphatic network which maintains the solute and fluid balance of peritoneal tissues and prevents formation of edema $(30,31)$. In the sub-mesothelial layer of the peritoneum, the terminal lymphatic capillaries are subdivided into parasternal, paravertebral, mediastinal, intercostal and retroperitoneal lymphatics. Parasternal, mediastinal and retroperitoneal lymphatics are arranged over the anterior, posterior and central part of the diaphragm, respectively. These terminal lymph capillaries unite together to form afferent collecting and prenodal lymphatic ducts which are then connected with regional lymph nodes. The parasternal, paravertebral and mediastinal lymphatics are connected with the mediastinal lymph nodes, whereas, retroperitoneal lymphatics are joined with cisternal and intestinal lymph nodes. From these lymph nodes the lymphatic system joins the venous circulatory system through thoracic duct and right lymphatic duct (32). 
Fig. I Panel (a), parietal mesothelial cell with small number of pinocytic vesicles and a more mature basement membrane. Panel (b), visceral mesothelial cell with higher number of pinocytic vesicles and less mature basement membrane
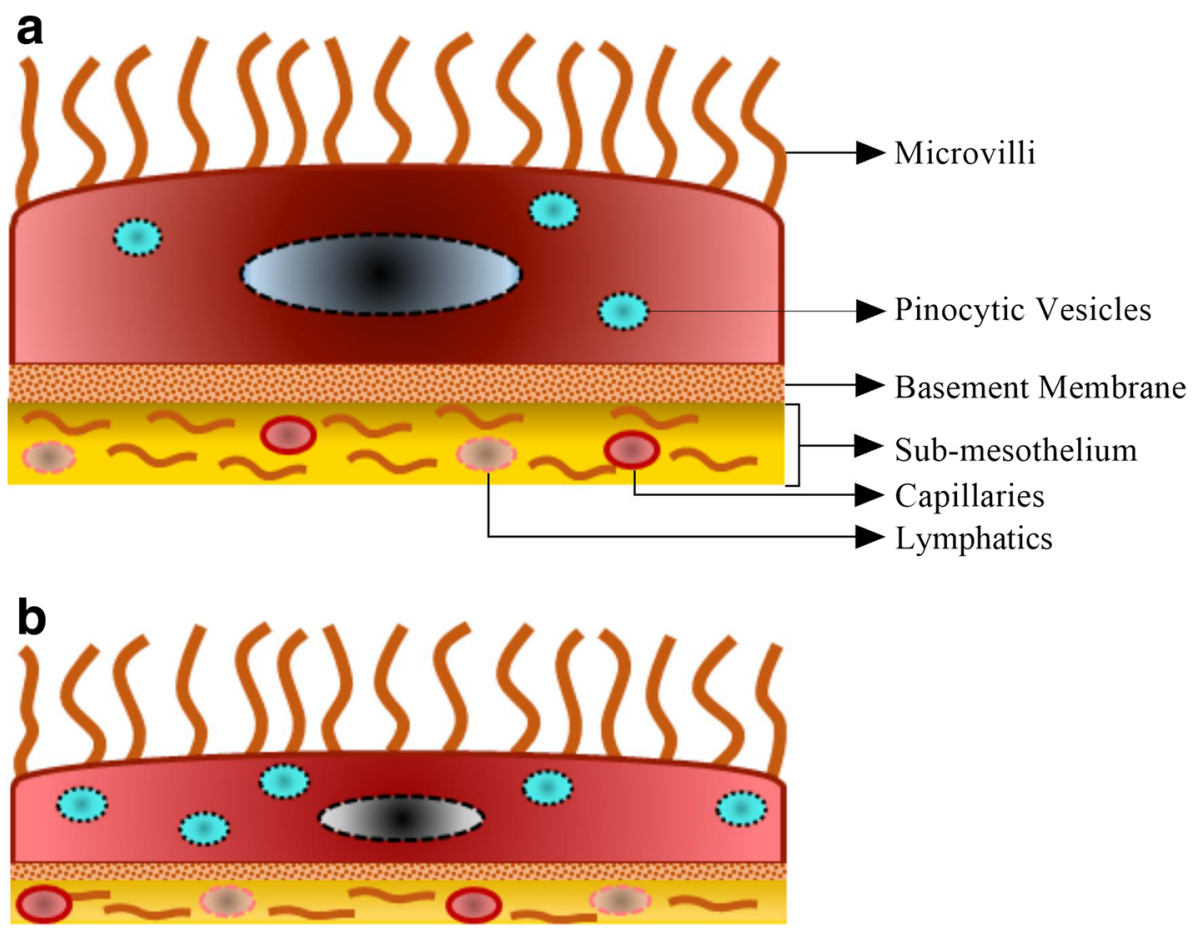

\section{ABSORPTION OF SOLUTES FROM THE PERITONEAL CAVITY, GENERAL CONSIDERATIONS}

Peritoneal cavity is an excellent portal of entry into systemic circulation for substances after IP administration. Its large surface area, estimated about $125 \mathrm{~cm}^{2}$ in an average rat, presence of microvilli on mesothelial cells and the vast blood supply facilitate rapid absorption of substances after IP administration $(33,34)$. Additionally, lymphatic transport of substrates significantly contributes to the total transfer from the peritoneal cavity to systemic circulation (35).

To reach the vascular compartment after IP administration, a compound must cross different structures in and around the peritoneal cavity including the peritoneal fluid, mesothelium, sub-mesothelium and blood vessel wall $(36,37)$. Transcellular and intercellular spaces in the visceral and parietal mesothelium are the main gateways for solutes and molecules to pass from the peritoneal cavity into surrounding tissues. Because of its structural features, visceral mesothelium is more permeable to molecules compared to parietal mesothelium. Anatomically, visceral peritoneum is composed of flat cells with large number of pinocytic vesicles which facilitate absorption of molecules. On the contrary, parietal peritoneum contains less pinocytic vesicles and has a more developed basement membrane/connective tissue which make it less permeable for molecules (Fig. 1) (38).

Experimental studies indicate that small to medium size molecules (MW < 5000) and fluids are predominantly absorbed from visceral peritoneum by diffusion through the splenic, inferior and superior mesenteric capillaries and drain into the portal vein (39). On the other hand, large molecules (MW > 5000), proteins, blood and immune cells are taken up by the lymphatics (Fig. 2) (40). It is noteworthy, that there is some amount of retrograde movement, of both small and large molecules, from capillaries to peritoneal cavity, however it minimally affects the overall absorption of pharmacological agents from peritoneal cavity to systemic circulation $(41,42)$.

The physiological mechanisms of fluid and solute movement from peritoneal cavity-to-blood or blood-to-peritoneal cavity are the same, either through diffusion or convection. Rapid absorption of small molecules from the peritoneal cavity into blood capillaries are mainly governed by effective surface area $(\mathrm{A})$, solute concentration gradient $(\Delta \mathrm{C})$ and solute permeability $(\mathrm{Ps})(42,43)$.

Mass transfer of solute $(\mathrm{Js})=\mathrm{A} * \Delta \mathrm{C} * \mathrm{Ps}$

In case of IP administration, the effective surface area $(\mathrm{A})$ is created by the microvilli on mesothelial cells, which ensure increased absorption of IP administered substances. Because substances are efficiently carried away by capillary blood flow, a constant concentration gradient $(\Delta \mathrm{C})$ is available between the absorption site of the peritoneal cavity and surrounding capillaries. This concentration gradient facilitates the diffusion of administered substances from peritoneal cavity into blood capillaries. Lastly, physicochemical properties of the administered substance determine its permeability $(\mathrm{Ps})$ and hence absorption from peritoneal cavity. A highly lipophilic substance has a higher distribution rate into tissues, which results in 
Fig. 2 Schematic overview of absorption pathways for small and macromolecules from the peritoneal cavity to systemic circulation.
Small Molecules

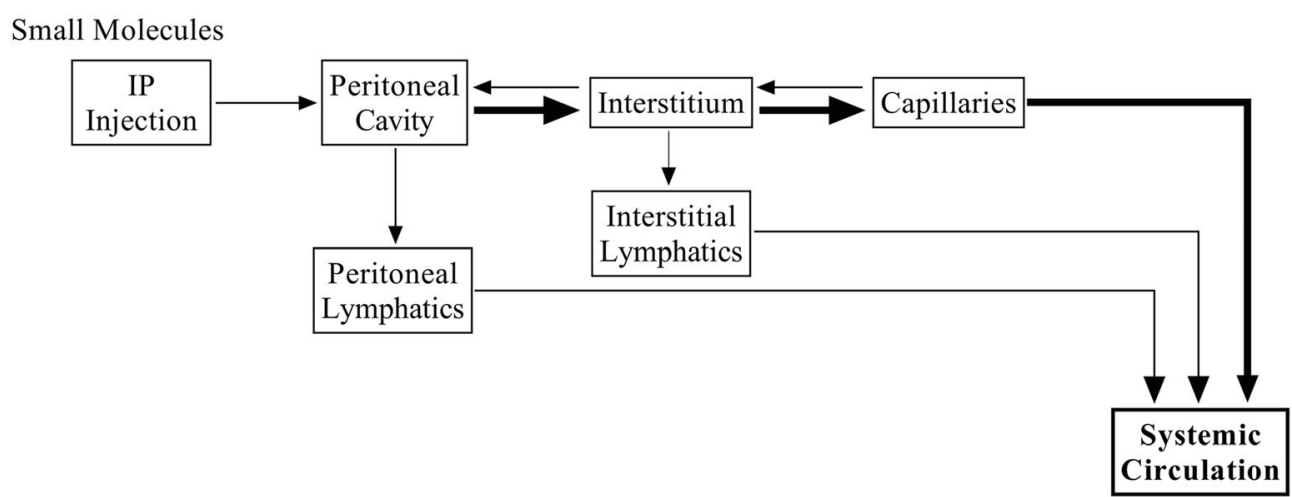

Macromolecules

Systemic

Circulation

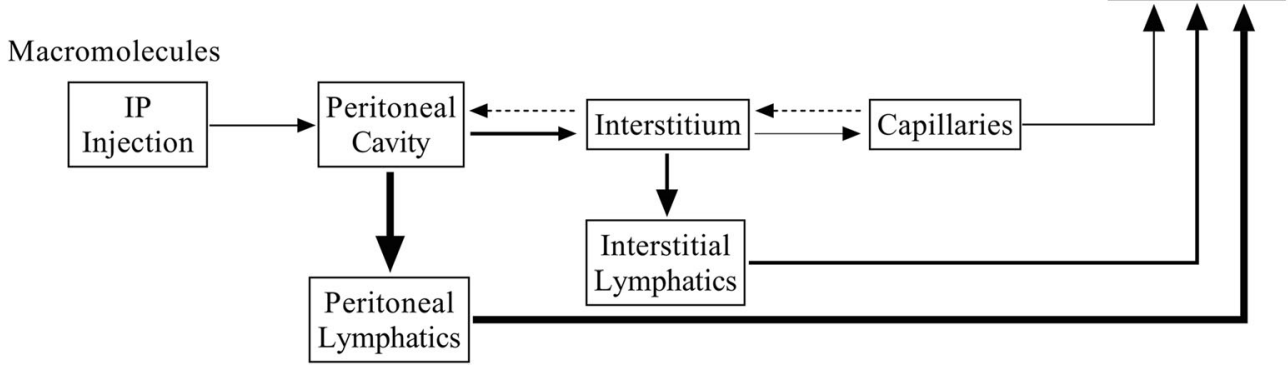

rapid removal of substance from the systemic circulation. The latter increases the concentration gradient between blood capillaries and peritoneal cavity, and leads to increased absorption rate of the substance after IP administration (44). Notably, solute permeability is the main determinant of convection rate, whereas concentration gradient is the main driving force for diffusion (45).

\section{CAPILLARY ABSORPTION OF SOLUTES AFTER IP ADMINISTRATION}

In the peritoneal microvascular network, majority of the solute and fluid exchange between peritoneal cavity and circulatory system occurs through capillaries. The capillary walls of the peritoneal capillaries are 'continuous' type, lined with single layer of continuous endothelial cells and basal lamina. These endothelial cells are very thin $(0.5 \mu \mathrm{m})$ and highly permeable $(46,47)$, plus they contain a large number of cytoplasmic vesicles (48-50). Intracellular clefts (6-7 nm thin channels located between adjacent endothelial cells) are also present in these capillaries which ensure rapid passage of water soluble ions and small molecules (21). Absorption of molecules with molecular size of $<20,000$ Da from peritoneal cavity occurs by either diffusion or convection through these capillaries $(42,51)$. The rate and extent of diffusion depends on the size, charge, configuration and concentration gradient of the molecules (52). In addition, IP administration of a drug in solution increases the IP hydrostatic pressure which drives the convection of the soluble drugs along with fluid through peritoneum into the blood capillaries (45). Molecules absorbed from the visceral peritoneum, mesentery and omentum are drained into the portal vein, while molecules absorbed form the parietal peritoneal blood capillaries and lymphatics drains directly into the systemic circulation $(53,54)$. Substances entering through portal circulation merge with systemic circulation after passing through liver which results in fast pass metabolism of the administered substances.

In one extensive experimental study carried out in rats, Lukas and colleagues have shown that after IP administration of small molecules (atropine, caffeine, glucose, glycine and progesterone), the primary route of absorption is through portal circulation (29). In this study the small molecules were selected to represent different physicochemical properties (basic, nonionic hydrophilic, zwitterionic and nonionic hydrophobic) and it was revealed that they all had comparable absorption pattern. In addition, the rate of absorption between IP and sub-cutaneous (SG) administrations of these 
compounds was compared. IP administered compounds could be detected in systemic circulation as soon as after $10 \mathrm{~s}$ of administration whereas it took about $60 \mathrm{~s}$ for SC administered compounds to reach systemic circulation. Another notable distinction between these two routs was the substantially lower degree of liver exposure and hence less biotransformation of molecules administered SC (29). Additionally, lipid solubility of IP administered compounds can affect the rate of their absorption. In general, increased lipid solubility leads to increased absorption from peritoneal cavity; e.g. only $\sim 57.4 \%$ of barbital (lipid-water partition co-efficient of 0.001) was shown to be absorbed after IP administration in the rat, whereas absorption of thiopental (lipid-water partition co-efficient of 3.3) was shown to be $96.1 \%$ in the same study (55). Another important factor in absorption of IPadministered compounds is their ionization state at physiologic $\mathrm{pH}$, which can be affected by buffering capacity of the peritoneal cavity (55). In general, absorption of IPadministered acidic substances increases as their pKa increases, e.g. benzyl penicillin with pKa of 2.8 has an absorption of $16.5 \%$, whereas secobarbital with pKa of 7.9 has an absorption of $87 \%$ (55). On the other hand, absorption of IPadministered basic substances decreases as their pKa increases, e.g. caffeine with $\mathrm{pKa}$ of 0.9 has an absorption of $68.3 \%$, whereas atropine with pKa of 9.6 has an absorption of $27 \%$ (55). Overall, unionized compounds are absorbed to a greater extent after IP administration than ionized compounds. Importantly, viscosity of the IP-administered formulations can also affect the absorption of pharmacological agents, with higher viscosity leading to decreased absorption and efficacy (55).

\section{LYMPHATIC ABSORPTION OF SOLUTES AFTER IP ADMINISTRATION}

Cellular arrangement around the peritoneum and ample supply of blood and lymph vessels assures rapid absorption of not only small molecules but also proteins and cells after IP administration $(56,57)$. Molecules with molecular weight larger than 30,000 Da enter the systemic circulation from the peritoneal cavity primarily via lymphatic vessels (41). Experimental studies indicate that IP administered plasma proteins are completely absorbed into systemic circulation and are distributed throughout the body similar to IV administered plasma proteins (58). Following IP administration, proteins are absorbed by lymphatic vessels, which are especially enriched around the diaphragm in most mammals including mouse, rat, dog, cat and human $(59,60)$. In addition to proteins, small particles and cells are also absorbed mainly through end lymphatic vessels, which are also known as stomata $(61,62)$. The peritoneal stomata are physiological openings in the peritoneum. Here, the mesothelial cells are interrupted and share a common basement membrane with lymphatic endothelium which allows a direct communication between peritoneal cavity and underlying lymphatics (11). Notably, relaxation of the diaphragm during respiration also controls the absorption of macromolecules from the peritoneal cavity (63). The diaphragm relaxes during expiration and the adjacent mesothelial cells on the border of lacunae separate from each other creating suction force and facilitating absorption of macromolecules. However, contraction during inspiration results in closing of gaps between mesothelial cells and emptying of lacunae into the efferent lymphatics. The parasternal lymphatics located in the diaphragm, especially in the right half around the liver, are mainly responsible for the transfer of peritoneal deposits form peritoneal cavity into the mediastinal nodes and then into venous circulation through the right lymphatic duct $(32,62)$. A small portion of peritoneal deposits are also drained through the paravertebral and mediastinal lymphatics situated on the parietal peritoneum, mesenteric, and omentum (60). The visceral lymphatics collect solutes and fluids from the omentum as well as mesentery and drain into the complex network of visceral lymph nodes. Subsequently, these visceral lymphatics collectively drain into parietal lymph nodes and finally dump the contents into venous circulation primarily through the thoracic duct (64). Quantitatively, about $75 \%$ of the absorbed proteins are drained into the right lymph duct and about $25 \%$ into the thoracic duct, which subsequently merge with venous circulation (Fig. 3) (57,65). Notably, obstruction of the right lymphatic and thoracic ducts does not prevent systemic absorption of proteins from the peritoneal cavity because trace amounts of proteins can still be absorbed through other small lymphovenous communications and capillary walls (60).

\section{PHARMACOKINETICS OF SMALL MOLECULES ADMINISTERED VIA IP VS OTHER ROUTES}

Recently, Durk and colleagues carried out a comprehensive study in rats to compare the pharmacokinetic parameters of IP and SC administered 9 small molecules (carbamazepine, citalopram, desmethylclozapine, diphenhydramine, gabapentine, metaclopramide, naltrexone, quinidine and risperidone) with distinct physicochemical properties (66). For all molecules, administered at $1 \mathrm{mg} / \mathrm{kg}$ dose, IP administration yielded higher $\mathrm{C}_{\max }$ and lower $\mathrm{t}_{\max }$ values in comparison to the $\mathrm{SC}$ route (Table I). The authors also compared $\mathrm{AUC}_{0-360}$ ratio of the brain interstitial fluid and plasma for all 9 molecules after IV infusion $(1 \mathrm{mg} / \mathrm{kg} / \mathrm{h}$ for $6 \mathrm{~h}$ ) or 3 intermittent doses of IP or SC injections ( $2 \mathrm{mg} / \mathrm{kg}$, every $2 \mathrm{~h}$ ) (66-68). These experiments revealed that after IP administration, the brain to plasma ratios were greater than 1 for diphenhydramine and naltrexone, close to 1 for carbamazepine, metaclopramide and risperidone, and substantially less than 1 for 


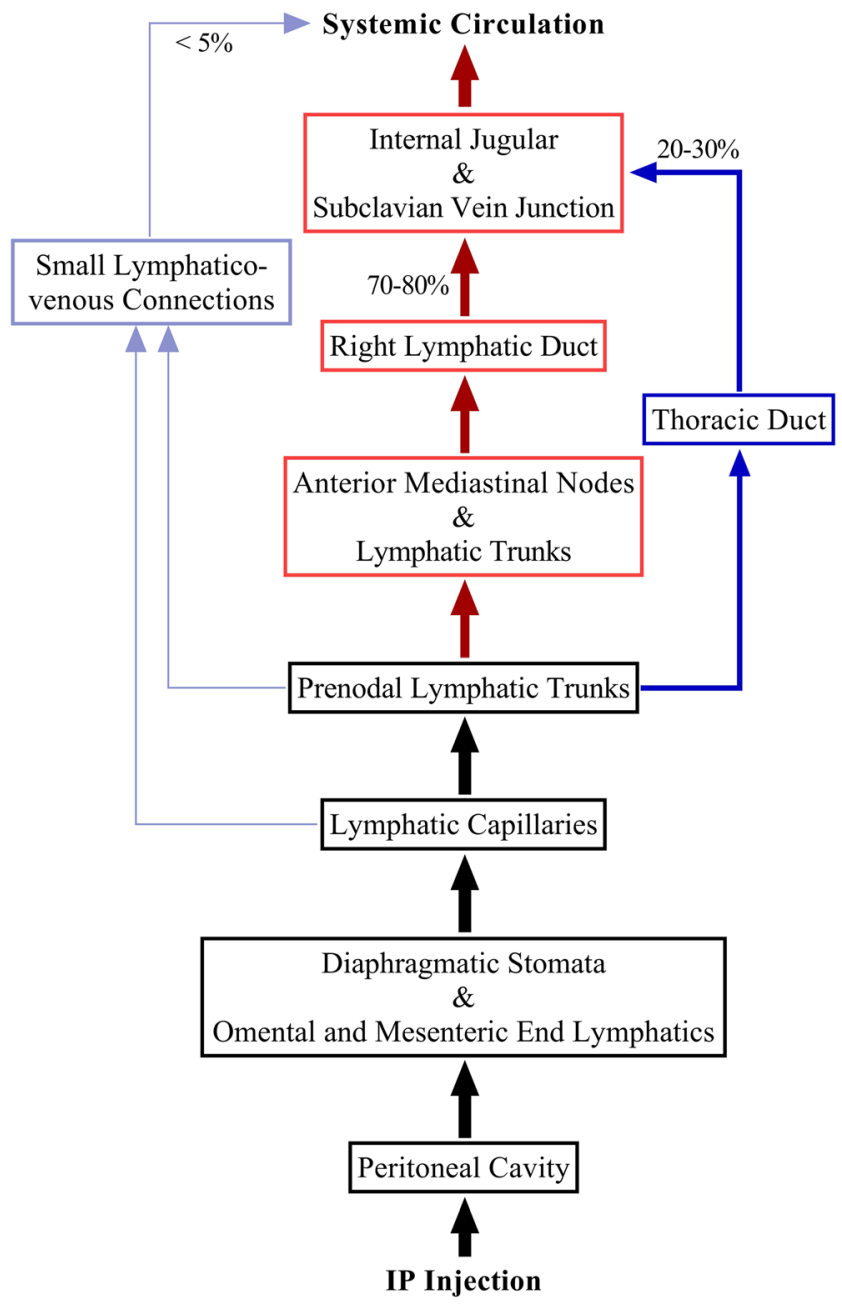

Fig. 3 Schematic representation of the main lymphatic absorption pathways for macromolecules after IP administration.

citalopram, desmethylclozapine, gabapentin and quinidine. Notably, brain exposure of most compounds were higher after IP or SC administration in comparison to IV infusion which could be due to saturation of transporters at the blood brain barrier and rapid elimination rate after IV infusion (Table II).

Several other studies also compared pharmacokinetic properties of small molecular drugs administered via IP and other routs (Table III). Among them, a study carried out by Shimada and colleagues compared plasma and peritoneal concentrations of docetaxel $(8 \mathrm{mg} / \mathrm{kg}, \mathrm{MW}=807.89)$ after IP and IV administration in mice (69). In intact mice, AUC of 4.85 and $3.37 \mathrm{mg} \mathrm{h} / \mathrm{ml}$ were observed after IV and IP administration of the drug, respectively. Based on these data the calculated absolute bioavailability $\left(\mathrm{F}^{\%} \%=\mathrm{AUC}\right.$ IP/AUC IV $\times 100 \%$ ) of IP administered docetaxel is $69 \%$ (69), which is much higher compared to the absolute bioavailability of docetaxel after oral administration $(\sim 2.8 \%)(70)$. Notably, the documented maximum plasma concentration $\left(\mathrm{C}_{\max }\right)$ of docetaxel was also similar after IP and IV administration in this study.
In another study, the plasma profile of deramciclane $(10 \mathrm{mg} / \mathrm{kg}, \mathrm{MW}=301.466)$ was compared after oral, IP and IV administration in rats (71). Deramciclane showed $\mathrm{AUC}_{0-\infty}$ of $106.95,578.18$ and $3127.53 \mathrm{ng}-\mathrm{h} / \mathrm{ml}$ after oral, IP and IV administration, respectively. The absolute bioavailability of the drug was almost 6-fold higher after IP vs oral administration. Furthermore, the time required to reach maximum plasma concentration of the drug was 4 times shorter after IP vs oral administration. Importantly, in case of both oral and IP routes of administration deramciclane had poor bioavailability due to heavy first pass metabolism in the liver.

One other study compared pharmacokinetic profile of IP vs oral or IV administered ${ }^{18} \mathrm{~F}$-fluorodeoxyglucose (FDG, $\mathrm{MW}=181.15 \mathrm{~g} / \mathrm{mol}$ ) for positron emission tomography $/$ computed tomography (PET/CT) in mice (72). The authors concluded that the AUC and tissue uptake of FDG was greater in case of IP administration compared to the oral route. The time to reach maximum tissue concentration $\left(t_{\max }\right)$ was shorter after IP administration indicating a more rapid absorption of FDG after IP vs oral administration. Notably, the brain accumulation of FDG was not significantly different after IP or IV administration, however, it was lower after oral administration (72).

In another recent study, Matzneller and colleagues compared bioavailability of tariquidar $(\mathrm{MW}=646.73 \mathrm{~g} / \mathrm{mol})$ at $15 \mathrm{mg} / \mathrm{kg}$ dose in two different formulations after oral, IP and IV administration in rats (73). For formulation A (tariquidar dissolved in $5 \%$ glucose and $2 \%$ DMSO solution), the AUC were $18.1 \mu \mathrm{g} . \mathrm{h} / \mathrm{ml}, 23.8 \mu \mathrm{g} . \mathrm{h} / \mathrm{ml}$ and $25.2 \mu \mathrm{g} . \mathrm{h} / \mathrm{ml}$ after oral, IP and IV administration, respectively. Whereas, $\mathrm{C}_{\max }$ were $1.2 \mu \mathrm{g} / \mathrm{ml}, 1.5 \mu \mathrm{g} / \mathrm{ml}, 1.9 \mu \mathrm{g} / \mathrm{ml}$ and $\mathrm{t}_{\max }$ were $4 \mathrm{~h}, 2 \mathrm{~h}$, and $0.5 \mathrm{~h}$ after oral, IP and IV administration, respectively. These parameters were further improved in formulation B (microemulsion of tariquidar), for which AUC were $21.9 \mu \mathrm{g} . \mathrm{h} / \mathrm{ml}$, $25.6 \mu \mathrm{g} . \mathrm{h} / \mathrm{ml}$ and $25.2 \mu \mathrm{g} . \mathrm{h} / \mathrm{ml}, \mathrm{C}_{\max }$ were $1.3 \mu \mathrm{g} / \mathrm{ml}$, $1.6 \mu \mathrm{g} / \mathrm{ml}, 1.9 \mu \mathrm{g} / \mathrm{ml}$ and $\mathrm{t}_{\max }$ were $3.6 \mathrm{~h}, 2 \mathrm{~h}$, and $0.5 \mathrm{~h}$ after oral, IP and IV administration, respectively. Notably, for both formulations, the absolute bioavailability $(\mathrm{F} \%)$ was higher after IP vs oral administration; for formulation A, $\mathrm{F} \%$ was 71.6 and 91.4 after oral and IP administration, for formulation B, $\mathrm{F} \%$ was 86.3 and 99.6, respectively.

In a similar study carried out in mice, it was revealed that IP administered lenalidomide (MW $=259.261 \mathrm{~g} / \mathrm{mol}$ ) has better bioavailability compared to oral administration (74). Administration of the drug at $10 \mathrm{mg} / \mathrm{kg}$ dose resulted in AUC of $214 \mu \mathrm{g} \cdot \mathrm{min} / \mathrm{ml}, 300 \mu \mathrm{g} \cdot \mathrm{min} / \mathrm{ml}$ and $284 \mu \mathrm{g} . \mathrm{min} /$ $\mathrm{ml}$ after oral, IP and IV administration, respectively. The absolute bioavailability $(\mathrm{F} \%)$ was 75 and 105 after oral and IP administration, respectively. Whereas, the absorption rate was higher after IP vs oral administration, with an absorption constant $\left(\mathrm{K}_{\mathrm{a}}\right)$ of $0.044 \mathrm{~min}^{-1}$ and $0.014 \mathrm{~min}^{-1}$, respectively.

In summary, these experimental studies indicate that IP administration of small molecule pharmacological agents 
Table I Pharmacokinetic Parameters of 9 Distinct Small Molecules After IP and SC Administration in the Rat (Tabulated from Data Reported in Durk et al., 2018)

\begin{tabular}{|c|c|c|c|c|c|c|}
\hline Drug & MW* & Charge & Route & $\mathrm{C}_{\max }(\mathrm{ng} / \mathrm{ml})$ & $t_{\max }(h)$ & $t_{1 / 2}(h)$ \\
\hline \multirow[t]{2}{*}{ Carbamazepine } & \multirow[t]{2}{*}{236} & \multirow[t]{2}{*}{ Neutral } & SC & $305 \pm 132$ & $0.41 \pm 0.76$ & $2.87 \pm 2.09$ \\
\hline & & & IP & $426 \pm 191$ & $0.11 \pm 0.98$ & $0.74 \pm 0.18$ \\
\hline \multirow[t]{2}{*}{ Citalopram } & \multirow[t]{2}{*}{324} & \multirow[t]{2}{*}{ Basic } & SC & $95.6 \pm 36.3$ & $0.50 \pm 0$ & $1.17 \pm 0.04$ \\
\hline & & & $\mathbb{I P}$ & $106 \pm 67.1$ & $0.36 \pm 0.55$ & $|.33 \pm 0.6|$ \\
\hline \multirow[t]{2}{*}{ Desmethylclozapine } & \multirow[t]{2}{*}{313} & \multirow[t]{2}{*}{ Basic } & SC & $212 \pm 62.3$ & $1.17 \pm 0$ & $3.87 \pm 1.35$ \\
\hline & & & $\mathbb{I P}$ & $268 \pm 112$ & $1.01 \pm 0$ & $2.83 \pm 0.46$ \\
\hline \multirow[t]{2}{*}{ Diphenhydramine } & \multirow[t]{2}{*}{255} & \multirow[t]{2}{*}{ Basic } & SC & $44.5 \pm 21.9$ & $0.50 \pm 0.57$ & $0.84 \pm 0.33$ \\
\hline & & & $\mathbb{I P}$ & $38.7 \pm 15.5$ & $0.044 \pm 0.28$ & $0.90 \pm 0.47$ \\
\hline \multirow[t]{2}{*}{ Gabapentine } & \multirow[t]{2}{*}{$17 \mid$} & \multirow[t]{2}{*}{ Zwitter } & SC & $657 \pm 127$ & $1.67 \pm 0.57$ & $5.88 \pm 2.44$ \\
\hline & & & $\mathbb{I P}$ & $1060 \pm 305$ & $0.833 \pm 0.28$ & $3.93 \pm 1.15$ \\
\hline \multirow[t]{2}{*}{ Metaclopramide } & \multirow[t]{2}{*}{300} & \multirow[t]{2}{*}{ Basic } & SC & $49.9 \pm 17.2$ & $0.50 \pm 0$ & $4.25 \pm 6.1$ \\
\hline & & & IP & $74.8 \pm 43.6$ & $0.04 \pm 0$ & $0.61 \pm 0.12$ \\
\hline \multirow[t]{2}{*}{ Naltrexone } & \multirow[t]{2}{*}{341} & \multirow[t]{2}{*}{ Basic } & SC & $105 \pm 30.3$ & $0.41 \pm 0.14$ & $3.68 \pm 5.43$ \\
\hline & & & $\mathbb{I P}$ & $128 \pm 26.4$ & $0.19 \pm 0.26$ & $1.16 \pm 1.30$ \\
\hline \multirow[t]{2}{*}{ Quinidine } & \multirow[t]{2}{*}{324} & \multirow[t]{2}{*}{ Basic } & SC & $84.7 \pm 32.8$ & $0.66 \pm 0.28$ & $0.99 \pm 0.32$ \\
\hline & & & IP & $111 \pm 65.5$ & $0.11 \pm 0.12$ & $0.72 \pm 0.24$ \\
\hline \multirow[t]{2}{*}{ Risperidone } & \multirow[t]{2}{*}{410} & \multirow[t]{2}{*}{ Basic } & SC & $156 \pm 68.9$ & $0.66 \pm 0.28$ & $3.19 \pm 3.35$ \\
\hline & & & IP & $169 \pm 67.5$ & $0.04 \pm 0$ & $0.72 \pm 0.28$ \\
\hline
\end{tabular}

*, molecular weight in g/mol; values are mean \pm S.D. results in faster and more complete absorption compared to oral and SC routes. Given the fast absorption of most substances from peritoneal cavity, it is generally considrered that systemic exposure ( $\mathrm{AUC}$ and $\mathrm{C}_{\max }$ ) of a IP-admnistered substance is closer to that of the IV route. However, it is difficult to state how similar the exposure profiles are for the two routes, expecially considering that IP-administered substances are subject to first pass metabolism similar to orally administered substances $(29,75)$. The uncertaininty is reasoned by a close examination of the published literature indicating that a good number of pharmacokinetic studies comparing IP and other routes, did not consider the rapid absorbtion of substances from peritoneal cavity and did the first blood sampling $30 \mathrm{~min}$ after IP administration (69,73,76). For rapidly absorbed compounds such experimental design could substantially underestimate systemic exposure of the pharmacological agent after IP administration, and provide an indication of higher first pass metabolism. Unfortunately, analysis of the published studies does not allow to unequivocally conclude whether the first pass metabolism of IP-administered small molecules is as extensive as in case of the oral route, and future studies specifically designed to answer this question will be needed to clarify the notion.
Table II Comparison of Brain to Plasma AUC of 9 Distinct Small Molecules After IV, SC and IP Administration in the Rat (Tabulated from Data Reported in Durk et al. 2018)

\begin{tabular}{|c|c|c|c|}
\hline \multirow[t]{2}{*}{ Drug } & \multicolumn{3}{|c|}{$A \cup C_{0-360, \text { ISF }} / A \cup C_{0-360, \text { plasma }}$} \\
\hline & $\begin{array}{l}\text { IV infusion } \\
(\mathrm{l} \mathrm{mg} / \mathrm{kg} / \mathrm{h} \text { for } 6 \mathrm{~h})\end{array}$ & $\begin{array}{l}\text { Subcutaneous } \\
(2 \mathrm{mg} / \mathrm{kg} \text { every } 2 \mathrm{~h} \times 3)\end{array}$ & $\begin{array}{l}\text { IP } \\
(2 \mathrm{mg} / \mathrm{kg} \text { every } 2 \mathrm{~h} \times 3)\end{array}$ \\
\hline Carbamazepine & $0.250 \pm 0.07$ & $0.779 \pm 0.06$ & $1.31 \pm 0.23$ \\
\hline Citalopram & $0.438 \pm 0.13$ & $0.450 \pm 0.28$ & $0.467 \pm 0.15$ \\
\hline Desmethylclozapine & $0.0902 \pm 0.06$ & NC & $0.098 \pm 0.04$ \\
\hline Diphenhydramine & $2.24 \pm 0.43$ & $2.43 \pm 0.95$ & $3.38 \pm 0.94$ \\
\hline Gabapentine & $0.0153 \pm 0.01$ & $0.0622 \pm 0.01$ & $0.0747 \pm 0.02$ \\
\hline Metaclopramide & $0.0905 \pm 0.02$ & $0.646 \pm 0.31$ & $0.747 \pm 0.13$ \\
\hline Naltrexone & $0.441 \pm 0.16$ & $1.55 \pm 0.67$ & $2.78 \pm 0.65$ \\
\hline Quinidine & $0.154^{\mathrm{a}}$ & NC & $0.143 \pm 0.05$ \\
\hline Risperidone & $0.620^{\mathrm{a}}$ & $0.776 \pm 0.64$ & $0.793 \pm 0.20$ \\
\hline
\end{tabular}

Values are mean \pm S.D. NC, not calculated in the original article. ${ }^{\text {a }}$, S.D. was not reported in the original article 
Table III Pharmacokinetic Parameters of Various Small Molecules After IP and Other Routes of Administration in Rodents

\begin{tabular}{|c|c|c|c|c|c|c|c|}
\hline \multirow[t]{2}{*}{ Drug name } & \multirow[t]{2}{*}{ MW* } & \multirow[t]{2}{*}{ Route } & \multirow[t]{2}{*}{ Dose** } & \multicolumn{3}{|c|}{ Pharmacokinetics } & \multirow[t]{2}{*}{ Ref. } \\
\hline & & & & AUC粎米 & $\mathrm{C}_{\max }{ }^{\#}$ & $\mathrm{t}_{\max }^{\# \#}$ & \\
\hline Docetaxel & 807.879 & $\begin{array}{l}\text { IV } \\
\text { IP }\end{array}$ & $\begin{array}{l}8 \\
8\end{array}$ & $\begin{array}{l}4850 \\
3370\end{array}$ & $\begin{array}{l}1.2 \\
1.2\end{array}$ & $\begin{array}{l}\text { NA } \\
\text { I }\end{array}$ & (69) \\
\hline \multirow[t]{2}{*}{ Deramciclane } & 301.466 & $\begin{array}{l}\text { IV } \\
\text { IP }\end{array}$ & $\begin{array}{l}10 \\
10\end{array}$ & $\begin{array}{l}3127.53 \\
578.18\end{array}$ & $\begin{array}{l}2643 \\
177.8\end{array}$ & $\begin{array}{l}\text { NA } \\
0.166\end{array}$ & (7I) \\
\hline & & Oral & 10 & 106.95 & 44.94 & 0.5 & \\
\hline \multirow[t]{2}{*}{$\begin{array}{l}\text { Tariquidar } \\
\text { (In DMSO) }\end{array}$} & 646.73 & $\begin{array}{l}\text { IV } \\
\text { IP }\end{array}$ & $\begin{array}{l}15 \\
15\end{array}$ & $\begin{array}{l}25,200 \\
23,800\end{array}$ & $\begin{array}{l}1.9 \\
1.5\end{array}$ & $\begin{array}{l}0.5 \\
2\end{array}$ & (73) \\
\hline & & Oral & 15 & 18,100 & 1.2 & 4 & \\
\hline \multirow[t]{2}{*}{$\begin{array}{l}\text { Tariquidar } \\
\text { (Microemulsion) }\end{array}$} & 646.73 & $\begin{array}{l}\text { IV } \\
\text { IP }\end{array}$ & $\begin{array}{l}15 \\
15\end{array}$ & $\begin{array}{l}25,200 \\
25,600\end{array}$ & $\begin{array}{l}1.9 \\
1.6\end{array}$ & $\begin{array}{l}0.5 \\
2\end{array}$ & (73) \\
\hline & & Oral & 15 & 21,900 & 1.3 & 3.6 & \\
\hline \multirow[t]{2}{*}{ Lenalidomide } & 259.261 & $\begin{array}{l}\text { IV } \\
\text { IP }\end{array}$ & $\begin{array}{l}10 \\
10\end{array}$ & $\begin{array}{l}284,000 \\
300,000\end{array}$ & $\begin{array}{l}158 \\
8.48\end{array}$ & $\begin{array}{l}\text { NA } \\
\text { NA }\end{array}$ & (74) \\
\hline & & Oral & 10 & 214,000 & 2.03 & NA & \\
\hline
\end{tabular}

*, molecular weight in g/mol; ***, dose in mg/kg; ***, AUC in $\mathrm{ng}-\mathrm{h} / \mathrm{ml}$; \#, $\mathrm{t}_{\max }$ in $\mathrm{h} ; \# \#, \mathrm{C}_{\max }$ in $\mu \mathrm{g} / \mathrm{ml}$; NA, not available

\section{PHARMACOKINETICS OF MACROMOLECULES ADMINISTERED VIA IP VS OTHER ROUTES}

Numerous in vivo studies conducted in various animal models of disease have shown biological effect(s) of macromolecules and recombinant proteins after IP administration indicating bioavailability of large molecules administered by this route (77-80). In addition, some studies focused on complete or partial pharmacokinetic characterization of macromolecules after IP administration providing more detailed information about suitability of this route for administration of macromolecules (Table IV).

In an elegant study conducted in mice, Sumbria and colleagues investigated plasma and brain availability of IgG-TNF Decoy Receptor Fusion Protein (MW $=210 \mathrm{kDa}$ ) after IV, IP and $\mathrm{SC}$ administration at $0.7,3$ and $10 \mathrm{mg} / \mathrm{kg}$ doses (81). The observed $\mathrm{C}_{\max }$ values decreased in the following order IV > IP $>$ SC for all three doses. The calculated plasma AUC for $10 \mathrm{mg} / \mathrm{kg}$ dose were $10.8 \mathrm{mg} \cdot \mathrm{min} / \mathrm{mL}, 94.521 \mathrm{mg} \cdot \mathrm{min} / \mathrm{mL}$ and $17.233 \mathrm{mg} \cdot \mathrm{min} / \mathrm{mL}$ for $\mathrm{IV}_{0-1 \mathrm{~h}}, \mathrm{IP}_{0-24 \mathrm{~h}}$ and $\mathrm{SC}_{0-24 \mathrm{~h}}$ routes, respectively, indicating a 5.5-fold higher $\mathrm{AUC}_{0-24 \mathrm{~h}}$ after IP vs SC. Notably, while plasma concentrations of the noted groups were different, the brain concentrations were not different between IP and SC injections.

A recent comparative study carried out in neonatal rats evaluated the plasma and brain pharmacokinetics of recombinant human erythropoietin ( $\mathrm{rEpo}, \mathrm{MW}=37 \mathrm{kDa}$, administered IP or $\mathrm{SC}$ at $5000 \mathrm{U} / \mathrm{kg}$ ) (82). The calculated plasma $\mathrm{AUC}_{0-\infty}$ were 140,331 U.h/L, 117,677 U.h/L and brain AUC $_{0-24}$ were 52.5 U.h/L, 45.2 U.h/L after IP and SC administration, respectively. Plasma and brain $\mathrm{C}_{\max }$ were 10,015 U/L and $3.3 \mathrm{U} / \mathrm{g}$ after IP administration, and
$6224 \mathrm{U} / \mathrm{L}$ and $2.8 \mathrm{U} / \mathrm{g}$ after $\mathrm{SC}$ administration, respectively. Plasma $\mathrm{t}_{\max }$ was $3 \mathrm{~h}$ for IP and $9 \mathrm{~h}$ for $\mathrm{SC}$ administration.

In another study, Veronese and colleagues studied bioavailability of intact superoxide dismutase ( $\mathrm{SOD}, \mathrm{MW}=$ $37 \mathrm{kDa} ; 4000 \mathrm{IU}$ ) and monomethoxypoly-ethylene glycol (MPEG) conjugated SOD (3000 IU) after IV, IP, intramuscular (IM) and SC administration in the rat (83). In case of MPEG-conjugated SOD, the calculated AUC were 71, 54 and $29 \%$ of the administered dose after IP, IM and SC administration (compared to IV route), indicating the following order of bioavailability IV $>$ IP $>$ IM $>$ SC. The plasma $\mathrm{C}_{\max }$ values were $\sim 300 \mu \mathrm{g} / \mathrm{ml}, 100 \mu \mathrm{g} / \mathrm{ml}, 70 \mu \mathrm{g} / \mathrm{ml}$ and $62 \mu \mathrm{g} / \mathrm{ml}$ for IV, IP, IM and SC routes, whereas absorption rates decreased in following order $\mathrm{IP}>\mathrm{IM}>\mathrm{SC}$, and $\mathrm{t}_{\max }$ values were $10 \mathrm{~h}, 42 \mathrm{~h}$ and $40 \mathrm{~h}$, respectively. In comparison to AUC of IV administered MPEG-conjugated SOD, the observed AUC of intact SOD after IV, IP, IM and SC administration were $1.20,0.87,0.72$ and $0.59 \%$ indicating superior stability of the conjugated SOD over the intact form. The absorption rate of intact SOD was highest after IP administration, followed by IM and SC routes (IP $>$ IM $>$ SC), with $\mathrm{t}_{\max }$ values of $100 \mathrm{~min}, 150 \mathrm{~min}$ and $150 \mathrm{~min}$, respectively.

In another study, Parker and colleagues performed pharmacokinetic evaluation of Exendin-4 (a homolog of glucagonlike peptide-1 (7-36)amide, MW $=4186.63 \mathrm{Da})$ in rats (84). The observed AUC values were $172 \pm 5 \mathrm{nM} . \mathrm{h} / \mathrm{ml}, 128 \pm$ $25 \mathrm{nM} . \mathrm{h} / \mathrm{ml}$ and $112 \pm 18 \mathrm{nM} . \mathrm{h} / \mathrm{ml}$ following IV, IP and $\mathrm{SG}$ administration of $50 \mathrm{nmol}$ Exendin-4. It was also revealed that IP administration results in higher $\mathrm{C}_{\max }(35.3 \pm 6.1 \mathrm{nM})$ compared to $\mathrm{SC}(28 \pm 4 \mathrm{nM})$ administration, whereas elimination was also more rapid after IP $\left(\mathrm{t}_{1 / 2}=157 \mathrm{~min}\right)$ compared to $\mathrm{SC}\left(\mathrm{t}_{1 / 2}=216 \mathrm{~min}\right)$ administration. 
Table IV Plasma Pharmacokinetic Parameters of Various

Macromolecules After IV, IP and SC Routes of Administration in Rodents

\begin{tabular}{|c|c|c|c|c|c|c|c|}
\hline \multirow[t]{2}{*}{ । } & \multirow[t]{2}{*}{$\mathrm{MW}(\mathrm{kDa})$} & \multirow[t]{2}{*}{ Route } & \multirow[t]{2}{*}{ Dose } & \multicolumn{3}{|c|}{ Pharmacokinetics } & \multirow[t]{2}{*}{ Ref. } \\
\hline & & & & AUC* & $C_{\text {max }}{ }^{*}$ & $t_{\max }$ & \\
\hline \multirow[t]{2}{*}{$\operatorname{lgG}-\mathrm{TNF}$} & \multirow[t]{2}{*}{210} & $\begin{array}{l}\text { IV } \\
\text { IP }\end{array}$ & $\begin{array}{l}10 \mathrm{mg} / \mathrm{kg} \\
10 \mathrm{mg} / \mathrm{kg}\end{array}$ & $\begin{array}{l}10.8_{(0-1 h)} \\
94.52_{(0-24 h)}\end{array}$ & $\begin{array}{l}\sim 250 \\
120\end{array}$ & $\begin{array}{l}\text { NA } \\
6 \mathrm{~h}\end{array}$ & \multirow[t]{2}{*}{$(81)$} \\
\hline & & SC & 10 mg/kg & $17.23_{(0-24 h)}$ & 20 & $6 \mathrm{~h}$ & \\
\hline rEpo & 37 & $\begin{array}{l}\text { IP } \\
\text { SC }\end{array}$ & $\begin{array}{l}5000 \cup / k g \\
5000 \cup / k g\end{array}$ & $\begin{array}{l}|40,33| \\
\mid 17,677\end{array}$ & $\begin{array}{l}10,015 \\
6224\end{array}$ & $\begin{array}{l}3 \mathrm{~h} \\
9 \mathrm{~h}\end{array}$ & (82) \\
\hline \multirow[t]{3}{*}{ SOD } & \multirow[t]{3}{*}{37} & $\begin{array}{l}\text { IV } \\
\text { IP }\end{array}$ & $\begin{array}{l}4000 \mathrm{IU} \\
4000 \mathrm{IU}\end{array}$ & $\begin{array}{l}1.20 \%{ }^{a} \\
0.87 \%{ }^{a}\end{array}$ & $\begin{array}{l}300 \\
40\end{array}$ & $\begin{array}{l}\mathrm{NA} \\
1.67 \mathrm{~h}\end{array}$ & \multirow[t]{3}{*}{ (83) } \\
\hline & & $\mathbb{M}$ & $4000 \mathrm{IU}$ & $0.72 \%^{a}$ & 15 & $2.5 \mathrm{~h}$ & \\
\hline & & SC & $4000 \mathrm{IU}$ & $0.59 \%^{\mathrm{a}}$ & 18 & $2.5 \mathrm{~h}$ & \\
\hline \multirow[t]{3}{*}{ MPEG-SOD } & \multirow[t]{3}{*}{42} & $\begin{array}{l}\text { IV } \\
\text { IP }\end{array}$ & $\begin{array}{l}3000 \mathrm{IU} \\
3000 \mathrm{IU}\end{array}$ & $\begin{array}{l}100 \% \\
71 \%\end{array}$ & $\begin{array}{l}300 \\
100\end{array}$ & $\begin{array}{l}\mathrm{NA} \\
\mathrm{lOh}\end{array}$ & \multirow[t]{3}{*}{ (83) } \\
\hline & & $\mathbb{I M}$ & $3000 \mathrm{IU}$ & $54 \%$ & 70 & $42 \mathrm{~h}$ & \\
\hline & & SC & $3000 \mathrm{IU}$ & $29 \%$ & 62 & $40 \mathrm{~h}$ & \\
\hline \multirow[t]{2}{*}{ Exedin-4 } & \multirow[t]{2}{*}{4.186} & $\begin{array}{l}\text { IV } \\
\text { IP }\end{array}$ & $\begin{array}{l}50 \mathrm{nM} \\
50 \mathrm{nM}\end{array}$ & $\begin{array}{l}172 \\
128\end{array}$ & $\begin{array}{l}\text { NA } \\
35.3\end{array}$ & NA & \multirow[t]{2}{*}{ (84) } \\
\hline & & SC & $50 \mathrm{nM}$ & 112 & 28 & $0.5 \mathrm{~h}$ & \\
\hline \multirow[t]{2}{*}{ sIL-IR } & \multirow[t]{2}{*}{68} & $\begin{array}{l}\text { IV } \\
\text { IP }\end{array}$ & $\begin{array}{l}340 \mathrm{ng} \\
240 \mathrm{ng}\end{array}$ & $\begin{array}{l}\text { NA } \\
\text { NA }\end{array}$ & $\begin{array}{l}178 \\
32\end{array}$ & $\begin{array}{l}1 \mathrm{~min} \\
2 \mathrm{~h}\end{array}$ & \multirow[t]{2}{*}{$(85)$} \\
\hline & & SC & $240 \mathrm{ng}$ & NA & 14 & $4 \mathrm{~h}$ & \\
\hline \multirow[t]{2}{*}{ slL-4R } & \multirow[t]{2}{*}{140} & $\begin{array}{l}\text { IV } \\
\text { IP }\end{array}$ & $\begin{array}{l}1.1 \mu \mathrm{g} \\
1.1 \mu \mathrm{g}\end{array}$ & $\begin{array}{l}\text { NA } \\
\text { NA }\end{array}$ & $\begin{array}{l}1.2 \\
0.19\end{array}$ & $\begin{array}{l}2 \mathrm{~min} \\
\mathrm{I} \mathrm{h}\end{array}$ & \multirow[t]{2}{*}{ (85) } \\
\hline & & SC & I.l $\mu \mathrm{g}$ & NA & 0.21 & $\mathrm{l} h$ & \\
\hline \multirow[t]{2}{*}{ AD- I I4-PA600-6H } & \multirow[t]{2}{*}{60.6} & $\begin{array}{l}\text { IV } \\
\text { IP }\end{array}$ & $\begin{array}{l}10 \mathrm{mg} / \mathrm{kg} \\
10 \mathrm{mg} / \mathrm{kg}\end{array}$ & $\begin{array}{l}|87| \\
\mid 435\end{array}$ & $\begin{array}{l}467 \\
176\end{array}$ & $\begin{array}{l}1.8 \mathrm{~min} \\
2 \mathrm{~h}\end{array}$ & \multirow[t]{2}{*}{ (88) } \\
\hline & & SC & 10 mg/kg & 760 & 32.17 & $8 \mathrm{~h}$ & \\
\hline IFN-Y & 16.8 & $\begin{array}{l}\text { IP } \\
\text { SC }\end{array}$ & $\begin{array}{l}100 \mu \mathrm{g} / \mathrm{kg} \\
100 \mu \mathrm{g} / \mathrm{kg}\end{array}$ & $\begin{array}{l}12.54 \\
0.947\end{array}$ & $\begin{array}{l}3.41 \\
0.35\end{array}$ & $\begin{array}{l}2 \mathrm{~h} \\
2 \mathrm{~h}\end{array}$ & (89) \\
\hline PEG-IO- IFN-Y & $\sim 26$ & $\begin{array}{l}\text { IP } \\
\text { SC }\end{array}$ & $\begin{array}{l}100 \mu \mathrm{g} / \mathrm{kg} \\
100 \mu \mathrm{g} / \mathrm{kg}\end{array}$ & $\begin{array}{l}3.30 \\
1.12\end{array}$ & $\begin{array}{l}160.03 \\
15.62\end{array}$ & $\begin{array}{l}4 \mathrm{~h} \\
>24 \mathrm{~h}\end{array}$ & (89) \\
\hline PEG-20- IFN-Y & $\sim 36$ & $\begin{array}{l}\text { IP } \\
\text { SC }\end{array}$ & $\begin{array}{l}100 \mu \mathrm{g} / \mathrm{kg} \\
100 \mu \mathrm{g} / \mathrm{kg}\end{array}$ & $\begin{array}{l}6.4 \\
2.3\end{array}$ & $\begin{array}{l}179.5 \\
29.52\end{array}$ & $\begin{array}{l}4 \mathrm{~h} \\
>24 \mathrm{~h}\end{array}$ & (89) \\
\hline PEG-40- IFN-Y & $\sim 56$ & $\begin{array}{l}\text { IP } \\
\text { SC }\end{array}$ & $\begin{array}{l}100 \mu \mathrm{g} / \mathrm{kg} \\
100 \mu \mathrm{g} / \mathrm{kg}\end{array}$ & $\begin{array}{l}28.25 \\
2.12\end{array}$ & $\begin{array}{l}567.29 \\
23.47\end{array}$ & $\begin{array}{l}10 \mathrm{~h} \\
>24 \mathrm{~h}\end{array}$ & (89) \\
\hline Anti-CD20 mAb & 145 & $\begin{array}{l}\text { IP } \\
\text { SC }\end{array}$ & $\begin{array}{l}150 \mu \mathrm{g} \\
150 \mu \mathrm{g}\end{array}$ & $\begin{array}{l}106.63 \\
51.67\end{array}$ & $\begin{array}{l}0.195 \\
0.203\end{array}$ & $\begin{array}{l}\sim 24 \mathrm{~h} \\
\sim 24 \mathrm{~h}\end{array}$ & (90) \\
\hline phFVIII & $90-200$ & $\begin{array}{l}\text { IP } \\
\text { SC }\end{array}$ & $\begin{array}{l}50 \cup / k g \\
50 \cup / k g\end{array}$ & $\begin{array}{l}\text { NA } \\
\text { NA }\end{array}$ & $\begin{array}{l}\sim 300 \\
\#\end{array}$ & $\begin{array}{l}2-4 \mathrm{~h} \\
\mathrm{NA}\end{array}$ & $(91)$ \\
\hline ohWWF & 500-2000 & $\begin{array}{l}\text { IP } \\
\text { SC }\end{array}$ & $\begin{array}{l}50 \cup / k g \\
50 \cup / k g\end{array}$ & $\begin{array}{l}\text { NA } \\
\text { NA }\end{array}$ & $\begin{array}{l}\sim 250 \\
\#\end{array}$ & $\begin{array}{l}2-4 \mathrm{~h} \\
\mathrm{NA}\end{array}$ & (9I) \\
\hline GLP-I & $3297^{* * *}$ & $\begin{array}{l}\text { IP } \\
\text { SC }\end{array}$ & $\begin{array}{l}50 \mathrm{nM} \\
50 \mathrm{nM}\end{array}$ & $\begin{array}{l}0.77 \\
1.54\end{array}$ & $\begin{array}{l}2.64 \\
5.14\end{array}$ & $\begin{array}{l}\text { NA } \\
N A\end{array}$ & (84) \\
\hline
\end{tabular}

* Units for AUC and $\mathrm{C}_{\max }$ are different among various macromolecules, however, they are the same within the same study for different routes of administration (see details in the text where the specific study is discussed). ${ }^{a}, \% A \cup C$ in comparison to AUC of IV administered MPEG-SOD. \#, the protein was undetectable in plasma after SC administration. $\mathrm{NA}$, not available. **, MW in $\mathrm{g} / \mathrm{mol}$;
Additionally, pharmacokinetic parameters of radiolabeled soluble interlukin-1 receptor (IL-1R, MW $=68 \mathrm{kDa}$ ) were studied after IV (340 ng), IP (240 ng) and SC (240 ng) administration in mice (85). Though the study did not report AUC values, the observed $\mathrm{C}_{\max }$ was $178 \mathrm{ng} / \mathrm{mL}, 32 \mathrm{ng} / \mathrm{mL}$ and $14 \mathrm{ng} / \mathrm{mL}$, and $\mathrm{t}_{\max }$ was $1 \mathrm{~min}, 120 \mathrm{~min}$ and $240 \mathrm{~min}$ after IV,
IP and SC administration of IL-1R, respectively. In the same study, the authors studied pharmacokinetic properties of soluble interlukin-4 receptor (IL-4R, MW $=140 \mathrm{kDa}$ at $1.1 \mu \mathrm{g}$ ). For IL-4R the observed $\mathrm{C}_{\max }$ was $1.2 \mu \mathrm{g} / \mathrm{mL}, 0.19 \mu \mathrm{g} / \mathrm{mL}$, $0.21 \mu \mathrm{g} / \mathrm{mL}$, and $\mathrm{t}_{\max }$ was $2 \mathrm{~min}, 60 \mathrm{~min}, 60 \mathrm{~min}$ after IV, IP and $\mathrm{SC}$, respectively. 
To study the effect of dose and injection volume on pharmacokinetics of IP administered macromolecules, Barrett and colleagues injected two doses $\left(2\right.$ and $100 \mu \mathrm{g}$ ) of IgG2 $2_{\mathrm{ak}}(\mathrm{IgG}$ light chain, $\mathrm{MW}=25 \mathrm{kDa}$ ) at two different injection volumes (2 and $20 \mathrm{ml}$ ) in rats (86). Their observations revealed that higher dose of administered $\mathrm{IgG} 2_{\mathrm{ak}}$ results in higher AUC and $\mathrm{C}_{\max }$ whereas, the higher volume resulted in lower $\mathrm{AUC}$ and $\mathrm{C}_{\max }$. According to the authors and another research group (87), IP injection of higher volume induces diuresis and increased clearance of the drug leading to a lower AUC.

In another study, comparative pharmacokinetics of AD114-PA600-6H (human single domain antibody against CXCR4, MW $=60.6 \mathrm{kDa}$ ) at $10 \mathrm{mg} / \mathrm{kg}$ dose was studied in mice after IV, IP and SC administration (88). The results indicated higher $\mathrm{AUC}_{\text {last }}$ after IP administration compared to the SC, though the highest AUC was observed after IV administration; $\mathrm{AUC}_{\text {last }}$ for IV, IP and SC were $1871 \mu \mathrm{g} . \mathrm{h} /$ $\mathrm{mL}, 1435 \mu \mathrm{g} . \mathrm{h} / \mathrm{mL}$ and $760 \mu \mathrm{g} . \mathrm{h} / \mathrm{mL}$, respectively. The $\mathrm{C}_{\max }$ were $467 \mu \mathrm{g} / \mathrm{mL}, 176 \mu \mathrm{g} / \mathrm{mL}$ and $32.17 \mu \mathrm{g} / \mathrm{mL}$ with $\mathrm{t}_{\max }$ values of $1.8 \mathrm{~min}, 2 \mathrm{~h}$ and $8 \mathrm{~h}$ for IV, IP and SC administration of AD-114-PA600-6H, respectively.

A comprehensive pharmacokinetic study of IFN- $\gamma(\mathrm{MW}=$ $16.8 \mathrm{kDa}, 100 \mu \mathrm{g} / \mathrm{kg}$ ) and its PEG-ylated conjugates (with PEG-10, -20 and -40 at $100 \mu \mathrm{g} / \mathrm{kg}$ dose) in rats showed higher $\mathrm{AUC}_{0-\infty}$ and $\mathrm{C}_{\max }$ values after IP vs $\mathrm{SC}$ administration for all IFN- $\gamma$ forms (89). In addition, the observed $t_{\max }$ after IP administration was $4 \mathrm{~h}, 4 \mathrm{~h}, 10 \mathrm{~h}$ and $2 \mathrm{~h}$ for PEG-10, PEG20, PEG-40-conjugated and intact IFN- $\gamma$, respectively, whereas it exceeded $24 \mathrm{~h}$ for all PEG-ylated IFN- $\gamma$ and was $2 \mathrm{~h}$ for native IFN- $\gamma$ after $\mathrm{SC}$ administration. $\mathrm{C}_{\max }$ values were $160.03 \mathrm{ng} / \mathrm{mL}, 179.50 \mathrm{ng} / \mathrm{mL}, 567.29 \mathrm{ng} / \mathrm{mL}$ and $3.41 \mathrm{ng} / \mathrm{mL}$ after IP, and $15.62 \mathrm{ng} / \mathrm{mL}, 29.52 \mathrm{ng} / \mathrm{mL}$, $23.47 \mathrm{ng} / \mathrm{mL}$ and $0.35 \mathrm{ng} / \mathrm{mL}$ after $\mathrm{SC}$ administration for PEG-10, PEG-20, PEG-40-conjugated and intact IFN- $\gamma$, respectively.

In another study, pharmacokinetics of anti-CD-20 monoclonal antibody veltuzumab $(\mathrm{MW}=145 \mathrm{kDa}$, at $150 \mu \mathrm{g}$ ) was studied in mice after IP and SC administration (90). The calculated AUG was 106.639 nmole.h/mL after IP and 51.67 nmole.h/mL after $\mathrm{SC}$ administration. The observed $\mathrm{C}_{\max }$ were 0.195 and $0.203 \mathrm{nmole} / \mathrm{mL}$ for IP and SC administration, whereas $t_{\max }$ was $\sim 24 \mathrm{~h}$ for both routes.

In a recent study Shi and colleagues examined suitability of IP and SC routes, in comparison to IV, for administration of large plasma-derived proteins, coagulation factor VIII (phFVIII, MW =90-200 kDa, $50 \mathrm{U} / \mathrm{kg}$ ) and von Willebrand factor (phVWF, MW $=500-2000 \mathrm{kDa}, 50 \mathrm{U} /$ $\mathrm{kg}$ ) in mice (91). Both proteins were absorbed with $t_{\max }$ of 2 to $4 \mathrm{~h}$ after IP administration, with observed $\mathrm{C}_{\max }$ of $\sim 250 \mathrm{mU} / \mathrm{mL}$ for $\mathrm{phVWF}$ and $\sim 300 \mathrm{mU} / \mathrm{mL}$ for phFVIII, which is similar to plasma level of these proteins 2 to $4 \mathrm{~h}$ after IV administration. On the contrary, phVWF and phFVIII were undetectable after SC administration in mice, even though another coagulation factor with a smaller molecular size (FIX, MW = $55 \mathrm{kDa}$ ) was shown to be absorbed in significant amounts after SC administration in another study (92). Notably, Shi and colleagues concluded that the hindered absorption of phVWF and phFVIII after SC was likely due to their large molecular size retarding absorption through subcutaneous capillaries and lymphatics.

It is noteworthy, that not all studies documented better pharmacokinetic profile of IP vs SC administered ploypeptides or proteins. For example, in the study where Parkes and colleagues observed higher AUC of exendin-4 after IP vs SC administration, pharmacokinetics of glucagon-like peptide-1 (7-36) amide (also known as GLP-1) was also studied in the rat (84). Their observations revealed lower AUC for GLP-1 after IP vs SC administration, documenting AUC of $0.77 \pm$ $0.16 \mathrm{nM} . \mathrm{h} / \mathrm{ml}$ and $1.54 \pm 0.24 \mathrm{nM} . \mathrm{h} / \mathrm{ml}$, respectively. Additionally, $\mathrm{C}_{\max }$ after IP and SC administration of $50 \mathrm{nmol}$ GLP-1 were $2.64 \pm 2.11 \mathrm{nM}$ and $5.14 \pm 1.16 \mathrm{nM}$, respectively. The authors attributed these results to potential biodegradation of GLP-1 upon absorption from peritoneal cavity (84).

Collectively, based on the above-discussed experimental studies, we can suggest that macromolecules of different molecular size get access to systemic circulation after IP administration in intact/therapeutically active form and, in majority of cases, systemic exposure of these molecules, i.e. AUC, is higher after IP than SC route of administration (summarized in Table IV).

\section{BIOAVAILABILITY OF SUSPENSION AND NANOPARTICLE FORMULATIONS ADMINISTERED VIA IP ROUTE}

In addition to solution formulations of small and macromolecules discussed above, experimental studies point out to bioavailability of suspension formulations after IP administration. Absorption of suspension preparations after IP administration is mainly through lymphatic system and is primarily affected by physicochemical properties of the pharmacological agent, dissolution rate of the suspension in the peritoneal cavity and particle size (93). For example, in a recent study Cardenas and colleagues studied systemic bioavailability of 6 methylcoumarin (water insoluble, MW $=160.17 \mathrm{~g} / \mathrm{mol}$ ) in rats after IP and oral administration of $200 \mathrm{mg} / \mathrm{kg}$ suspension prepared in Tween-80 and saline (94). The authors observed more rapid absorption and higher bioavailability of the suspension after IP vs oral administration, documenting $t_{\max }$ values of $6 \mathrm{~min}$ and $30 \mathrm{~min}$, and AUC of $2177.0 \mu \mathrm{g} . \mathrm{min} / \mathrm{ml}$ and $977.2 \mu \mathrm{g} . \mathrm{min} / \mathrm{ml}$, respectively. On the other hand, systemic bioavailability of $100 \mathrm{mg} / \mathrm{kg}$ elacridar suspension (water insoluble, $\mathrm{MW}=563.6 \mathrm{~g} / \mathrm{mol}$ ), prepared in hydroxypropylmethylcellulose and Tween-80, after IP administration in 
mice was several fold lower compared to that of oral administration, with AUC of $90.30 \mu \mathrm{g} . \mathrm{min} / \mathrm{ml}$ and $1460 \mu \mathrm{g} . \mathrm{min} /$ $\mathrm{ml}$, respectively (95). Notably, when the same drug was given as a microemulsion (prepared with Cremophor EL, Carbiton and Captex 355) at $10 \mathrm{mg} / \mathrm{kg}$, systemic bioavailability of the formulation after IP administration was several times higher compared to oral administration, with AUC of $962 \mu \mathrm{g} . \mathrm{min} /$ $\mathrm{ml}$ and $270 \mu \mathrm{g} . \mathrm{min} / \mathrm{ml}$, respectively (76). The authors concluded that lower bioavailability of elacridar suspension compared to emulsion was due to lower dissolution of the administered formulation in the peritoneal cavity, which contains smaller amount of fluid compared to the gastrointestinal tract. It is noteworthy, that dissolution of the suspension formulation can be improved by vehicle selection. For instance, Sofia and colleagues have compared the influence of different suspension vehicles on central effects of $\Delta 9$-tetrahydrocannabinol (water insoluble, MW = $314.45 \mathrm{~g} / \mathrm{mol}$ ) at 10 and $40 \mathrm{mg} / \mathrm{kg}$ doses after IP administration (96). Among four different vehicles studied (bovine serum albumin-saline (BSA), 1\% Tween-80-saline, polyvinylpyrolidone-saline (PVP) and 10\% propylene glycol-1\% Tween 80 -saline (PG)), suspension of $\Delta$ 9-tetrahydrocannabinol in PG was the most effective followed by PVP suspension. In a subsequent study, the same investigators studied suspensions of $\Delta 9$-tetrahydrocannabinol in the same four vehicles after IV, IP, oral, and SC administration (97). The strongest CNS effects were observed with PG suspension and the effects descended in the following order IV $>$ IP $>$ SC $>$ oral, based on the route of administration (97). Lastly, particle size of the suspension formulation can also affect the efficacy of IP administered drugs. The latter was demonstrated by Ritschel and colleagues who studied toxicity of pentobarbiturate suspension in 1\% sodium-carboxymethyl cellulose at two different particle sizes $(<44 \mu \mathrm{m}$ and $297-$ $420 \mu \mathrm{m})$ administered IP in mice, and observed about twice higher toxicity of the drug at small vs large particle size suspension (LD50 of 189 and $288 \mathrm{mg} / \mathrm{kg}$, respectively) (98). Another recent study investigated pharmacokinetics of two poorly water soluble substances (at $5 \mu \mathrm{mol} / \mathrm{kg}$, referred to as AC88 and BA99) after IP administration in the rat, in the form of microsuspension (prepared with hydroxylpropylmethylcellulose) and nanosuspension (prepared with Aerosol OT, polyvinylpyrolidone and mannitol) (99). For both substances nanosuspensions showed about twice higher AUG compared to that of microsuspensions. More specifically, the observed $\mathrm{G}_{\max }, \mathrm{t}_{\max }$ and $\mathrm{AUC}$ values were $8.24 \mu \mathrm{mol} / \mathrm{L}, 3 \mathrm{~h}$ and $136 \mathrm{~kg} . \mathrm{h} / \mathrm{L}$ for AC88 microsuspension (mean size $14 \mu \mathrm{m}$ ), and $21.2 \mu \mathrm{mol} / \mathrm{L}, 2 \mathrm{~h}$ and $233 \mathrm{~kg} . \mathrm{h} / \mathrm{L}$ for AC88 nanosuspension (mean size 219-251 nm). Similarly, for BA99 microsuspension (mean size $12 \mu \mathrm{m}$ ) the observed $\mathrm{C}_{\max }, \mathrm{t}_{\max }$ and AUC values were $10.4 \mu \mathrm{mol} / \mathrm{L}, 0.7 \mathrm{~h}$ and $50.6 \mathrm{~kg} . \mathrm{h} / \mathrm{L}$, whereas for BA99 nanosuspension (mean size $291 \mathrm{~nm}$ ) the observed values were $20.1 \mu \mathrm{mol} / \mathrm{L}, 0.31 \mathrm{~h}$ and $85.4 \mathrm{~kg} . \mathrm{h} / \mathrm{L}$, respectively (99). Notably, the same research group studied bioavailability of
AC88 and BA99 nanosuspensions after oral and SC administration in the rat (at $5 \mu \mathrm{mol} / \mathrm{kg}$ ) in two parallel studies, and reported $\sim 5-8$ fold lower AUG values compared to IP administration of the same nanosuspensions $(100,101)$.

It is important to note, that while the small particle size of nanoformulations facilitates enhanced absorption of pharmacological agents, encapsulation of active substances in nanoformulations often results in decreased clearance from systemic circulation and ultimately higher drug exposure. In addition, depending on specifics of nanocapsulated formulation release of the drug may also be prolonged leading to higher drug exposure. For example, pharmacokinetic comparison of lipid core nanocapsule formulation of olanzapine (sparingly water soluble, $\mathrm{MW}=312.4 \mathrm{~g} / \mathrm{mol}$ ) with free olanzapine after IP administration (at $10 \mathrm{mg} / \mathrm{kg}$ ) indicated $\sim 2.3$ fold increased bioavailability of the nanoformulation in the rat (102). In addition, higher $\mathrm{G}_{\max }$ and lower clearance (CL) values were observed for olanzapine nanoformulation (3.02 $\mu \mathrm{g} / \mathrm{ml}$ and $1.36 \mathrm{~L} / \mathrm{h} / \mathrm{kg}$ ) compared to the free drug $(1.12 \mu \mathrm{g} / \mathrm{ml}$, and $3.12 \mathrm{~L} / \mathrm{h} / \mathrm{kg})$. And because the observed absorption rate was comparable for both formulations $\left(t_{\max }\right.$ $\sim 1 \mathrm{~h}$ ) the authors concluded that the observed higher bioavailability of nanoformulation was largely due to decreased CL (103). In another study, chitosan-coated PLGA nanoparticles of docetaxel (sparingly water soluble, MW $=807.87 \mathrm{~g} /$ mol) were studied in the rat after IP administration (at $13 \mathrm{mg} / \mathrm{kg}$ ) and $\sim 4.7$ fold higher bioavailability of the drug was observed for the nanoparticle formulation in comparison to free docetaxel suspension (103). Notably, the time to reach maximum plasma concentrations ( 2 and $0.5 \mathrm{~h}$ ) as well as the elimination half-life (5.2 and $2.6 \mathrm{~h}$ ) were higher for the nanoformulation, indicating overall longer residence time for docetaxel nanoparticle $(7.4 \mathrm{~h})$ in comparison to the free form (4.3 h) (102). Similarly, in a recent study Ragelle and colleagues studied bioavailability of free (at $223 \mathrm{mg} / \mathrm{kg}$ ) and nanoemulsion (at $112.5 \mathrm{mg} / \mathrm{kg}$, prepared with Miglyol ${ }^{\circledR}$ 812 N, Labrasol®, Tween-80, Lipoid® E80 and water) fisetin (sparingly water soluble, $\mathrm{MW}=286.23 \mathrm{~g} / \mathrm{mol}$ ) after IP administration in the rat (104). Their observations indicate that bioavailability of fisetin nanoemulsion was about 24 fold higher compared to the free drug, and it had to do with more rapid absorption (1.97 and $5.98 \mathrm{~h}$ ) and lower clearance (2.32 and $54.8 \mathrm{~L} / \mathrm{kg} / \mathrm{h}$ ) of the nanoemulsion vs free drug, respectively (104).

In summary, these experimental studies suggest that drugs in suspension and/or nanoparticle formulations also reach systemic circulation after IP administration. Notably, the physicochemical properties of the drug, dissolution rate of the suspension in the peritoneal cavity and particle size critically affect absorption rate and bioavailability of the administered drug. In general, higher dissolution rate and smaller particle size lead to more complete and rapid absorption of such formulations from peritoneal cavity and result in higher 
bioavailability. From the other hand, slow dissolution rate may lead to more prolonged absorption of the drugs from such formulations and also result in longer exposure. Lastly, encapsulation of active substances in nanoformulations may prolong release of the pharmacological agent into systemic circulation, and often leads to decreased clearance of the drug.

\section{LIMITATIONS OF THE IP ROUTE}

Eventhough IP administration of pharmacological agents results in faster and more complete absorption compared to oral, intramuscular and $\mathrm{SC}$ routes, this route as any other, has certain limitations. One limitation is the first pass metabolism, similar to what is observed with orally administered drugs, because substances absorbed from the peritoneal cavity end up in portal vein and pass through the liver. It is generally considered that, pharmacokinetics of small molecular drugs administered through the IP route resemble that of orally administered drugs in terms of metabolic fate and high rate of first pass metabolism, which leads to lower systemic exposure of IP-administered substances $(29,75)$. Notably, published literature does not allow to conclusively say whether the first pass metabolism of IP-administered sustances is as expensive as in case of the oral route and future studies will likely adress this question. On the contrary, IP administered macromolecules, which reach systemic circulation through lymphatic vessels, were shown to be minimally affected by first pass metabolism. This was well-documented with a number of recombinant enzymes including neurolysin (80), angiotensin converting enzyme 2 (105) and SOD (83) which retained catalytic activity upon reaching systemic circulation after IP administration in rodents.

Two other important considerations for IP administered agents include sterility and non-irritability, because irritating compounds may cause ileus and peritoneal inflammation, which may further develop into adhesions (106). Importantly, position of IP injection can aslo affect the absorption rate of substances. Although, not studied in experimental animals, a study carried out in humans showed that the time to reach maximum plasma concentration of insulin in healthy volunteers varied about 2-fold upon administration of the agent at a position above vs below the transverse mesocolon (107). The technique of injection and its accuracy may also affect the outcome of IP administration. One common mistake associated with IP drug admnistration ( $20 \%$ of cases) is puncturing the skin at a very sharp angle which results in $\mathrm{SC}$ administration rather than IP (108). Although occurring less frequently, inaccurate IP administration may also deposit drugs into the gastrointestinal tract, retroperitoneum or the urinary bladder (109). Another important factor is the volume of IP administered drugs because large volumes (>10 ml/ $\mathrm{kg}$ in rodents) can lead to pain, chemical peritonitis, formation of fibrous tissue, perforation of abdominal organs, hemorrhage, and respiratory distress (86,110,111). Repeated IP administration can result in a cumulative irritant effect and needle-induced damage of the peritoneum (5). Temperature of the IP administered solutions can also affect local absorption rate (112,113), whereas, hypothermia and distress can be observed if a large volume of a cold substance is administered IP $(114,115)$.

\section{CONCLUDING REMARKS}

Proper formulation of a drug and appropriate route of administration are crucial for clinical success at later stages of drug development. However, such questions are usually addressed after proof-of-concept studies where the goal is to evaluate the effect(s) of target engagement rather than properties of a drug formulation and/or its pharmacokinetics for clinical translation. Because of these reasons, in exploratory as well as early preclinical studies it is more practical to choose a route of drug administration that ensures bioavailability of the drug and meets the needs of a specific experiment/scientific question rather than focuses on clinically applicable administration route. In this regard, IP route of administration can be the choice for in vivo experimental studies in rodents, because it is safe for animals, ensures therapeutic bioavailability of both small and large molecules, amendable to variety of formulations, suitable for chronic treatments, robust and easy to master.

Among all routes of drug administration the IV route usually results in the highest bioavailability of a drug. However, this route is often impractical for rodent studies, because most investigational pharmacological agents are difficult to fully dissolve in water/aqueous solutions (hydrophobic nature), it requires advanced skills to practice (especially in mice, due to small vessels), and is not well-suited for chronic/repetitive treatments. To avoid these problems, researchers often prefer administration of pharmacological agents through oral, IP or $\mathrm{SC}$ routes, all of which have certain advantages and disadvantages (summarized in Table V). Among these, the IP route stands out because the rate and extent of drug absorption is faster in IP followed by intramascular $>\mathrm{SC}>$ oral routes (116), and it is suitable for both drug solutions and suspensions/emulsions. This is primarily because IP administered pharmacological agents are exposed to a large surface area (close to that of the entire skin surface) which leads to rapid and efficient absorption. Notably, in majority of cases the effect elicited by a pharmacological agent after IV administration can be approximated more closely with IP rather than intramuscular or SC administration. Usually, the rate of absorption after IP administration is one-half to one-fourth as rapid as after IV administration (66,69,117). Following rapid absorption from the peritoneal cavity, a compound may face one of the following two pathways to reach systemic circulation: (1) it is absorbed through the visceral peritoneum, the 
Table V Brief Comparison of Different Routes of Drug Administration in Laboratory Rodents

\begin{tabular}{|c|c|}
\hline \multicolumn{2}{|l|}{ IP route } \\
\hline Advantages & Disadvantages \\
\hline Convenient and easy to master & High first pass metabolism \\
\hline Less stressful/harmful for animals & Need for sterility \\
\hline $\begin{array}{l}\text { Suitable for variety of formulations (i.e., amendable to } \\
\text { physicochemical properties of a drug) }\end{array}$ & Abdominal organs can be injured if done incorrectly \\
\hline $\begin{array}{l}\text { Peritoneal cavity has buffering capacity } \\
\text { Large volumes can be administered }\end{array}$ & Limited clinical applicability \\
\hline \multicolumn{2}{|l|}{ Higher absorption rate } \\
\hline \multicolumn{2}{|l|}{ Suitable for repeated administrations } \\
\hline \multicolumn{2}{|l|}{ Suitable for administration of macromolecules } \\
\hline \multicolumn{2}{|l|}{ Oral Route } \\
\hline Advantages & Disadvantages \\
\hline Convenient and easy to master & Can be stressful for animals \\
\hline Suitable for repeated administrations & Can damage the esophagus \\
\hline Large volumes can be administered & Low absorption rate and poor bioavailability \\
\hline \multirow[t]{4}{*}{ Clinically applicable } & Food and pH may affect absorption \\
\hline & High first pass metabolism \\
\hline & Gut flora may contribute to metabolism \\
\hline & Usually not suitable for biological agents \\
\hline \multicolumn{2}{|l|}{ Intravenous Route } \\
\hline Advantages & Disadvantages \\
\hline No limitation in absorption & Isotonic solution of a drug is required \\
\hline Buffering capacity is present & Need for sterility \\
\hline Rapid onset of action & Technically challenging \\
\hline Suitable for administration of macromolecules & Can be stressful for animals \\
\hline \multirow[t]{2}{*}{ Clinically applicable } & Not suitable for large volume administration \\
\hline & Challenging for repeated administrations \\
\hline \multicolumn{2}{|l|}{ Subcutaneous Route } \\
\hline Advantages & Disadvantages \\
\hline Convenient and easy to master & Low absorption rate and poor bioavailability \\
\hline Less stressful/harmful for animals & Not suitable for large volume administration \\
\hline Suitable for most macromolecules & Local irritability \\
\hline Clinically applicable & Need for sterility \\
\hline
\end{tabular}

mesentery and omentum and is drained into portal circulation, or (2) the compound gets into the systemic circulation directly bypassing liver when it is absorbed through parietal peritoneum and lymphatics. Notably, small molecular weight compounds are primarily absorbed through the first pathway, because the surface area of membranes transporting substances into the portal circulation is much larger $(29,118)$. On the contrary, macromolecules access systemic circulation through the second pathway (lymphatics), which is very efficient but relatively less recognized among researchers.

Another important point of consideration is the suitability of IP route for chronic/repetitive treatments. For example, studies have shown that chronic IP administration (daily saline injection over 30 days in the same position of the abdomen) and use of different types of injection vehicles and volumes are safe and well-tolerated in laboratory animals $(119,120)$.
From a technical standpoint, IP administrations is more reproducible and easy to master compared to other available routs, and upon mastering it is less stressful and safer for rodents.

Among main deficiencies of the IP route, is the metabolic fate of IP administered small molecular agents, which resembles that of the orally administered drugs (121). This may present a problem for pharmacological agents prone to extensive first-pass metabolism.

In summary, based on the knowledge discussed in this manuscript we conclude that IP administration of drugs in experimental studies involving rodents is a justifiable route for initial pharmacological and proof-of-concept studies where the goal is to evaluate the effect(s) of target engagement rather than properties of a drug formulation and/or its pharmacokinetics for clinical translation. 


\section{ACKNOWLEDGMENTS AND DISCLOSURES}

Dr. Karamyan is supported by NIH (1R01NS106879) and AHA (14BGIA20380826) grants. We apologize that the scope of this manuscript prevented citation of all published experimental studies where the IP route of drug administration was used.

\section{REFERENCES}

1. Turner PV, Brabb T, Pekow C, Vasbinder MA. Administration of substances to laboratory animals: routes of administration and factors to consider. J Am Assoc Lab Anim Sci. 201 1;50(5):600-13.

2. Cunliffe-Beamer TLaL, E.P. . In The UFAW Handbook on the Care and Management of Laboratory Animals. Longman Scientific and Technical, Essex. 1987;6th:275-308.

3. Eldridge SF, McDonald, K.E., Renne, R.A. and Lewis, T.R. Lab Anim 11. 1982;11:50-54.

4. Simmons MLaB, J.O. . In The Laboratory Mouse (ed. A. Hollaender). Prentice-Hall Inc, Englewood Cliffs. 1970:127-129.

5. Morton DB, Jennings M, Buckwell A, Ewbank R, Godfrey C, Holgate B, Inglis I, James R, Page C, Sharman I, Verschoyle R, Westall L, Wilson AB, Joint Working Group on R. Refining procedures for the administration of substances. Report of the BVAAWF/FRAME/RSPCA/UFAW Joint Working Group on Refinement. British Veterinary Association Animal Welfare Foundation/Fund for the Replacement of Animals in Medical Experiments/Royal Society for the Prevention of Cruelty to Animals/Universities Federation for Animal Welfare. Lab Anim. 2001;35(1):1-41.

6. Wegner G. Chirurgische Bemerkungen uber die peritonealhohle, mit besonderer Berrucksichtigung der Ovariotomie. Langenbecks Arch Chir. 1877;20(51):145.

7. Hanbidge AE, Lynch D, Wilson SR. US of the peritoneum. Radiographics. 2003;23(3):663-84 discussion 684-665.

8. Hartveit F, Thunold S. Peritoneal fluid volume and the oestrus cycle in mice. Nature. 1966;210(5041):1123-5.

9. Aune S. Transperitoneal exchange. IV. The effect of transperitoneal fluid transport on the transfer of solutes. Scand J Gastroenterol. 1970;5(4):241-52.

10. Blackburn SC, Stanton MP. Anatomy and physiology of the peritoneum. Semin Pediatr Surg. 2014;23(6):326-30.

11. Michailova K, Wassilev W, Wedel T. Scanning and transmission electron microscopic study of visceral and parietal peritoneal regions in the rat. Ann Anat. 1999;181(3):253-60.

12. Albertine KH, Wiener-Kronish JP, Roos PJ, Staub NG. Structure, blood supply, and lymphatic vessels of the sheep's visceral pleura. Am J Anat. 1982;165(3):277-94.

13. Gotloib L, Digenis GE, Rabinovich S, Medline A, Oreopoulos DG. Ultrastructure of normal rabbit mesentery. Nephron. 1983;34(4):248-55.

14. Mutsaers SE, Whitaker D, Papadimitriou JM. Changes in the concentration of microvilli on the free surface of healing mesothelium are associated with alterations in surface membrane charge.J Pathol. 1996;180(3):333-9.

15. Whitaker D, Papadimitriou J. Mesothelial healing: morphological and kinetic investigations. J Pathol. 1985;145(2):159-75.

16. Shimotsuma M, Shields JW, Simpson-Morgan MW, Sakuyama A, Shirasu M, Hagiwara A, et al. Morpho-physiological function and role of omental milky spots as omentum-associated lymphoid tissue (OALT) in the peritoneal cavity. Lymphology. 1993;26(2): 90-101.
17. Stylianou E, Jenner LA, Davies M, Coles GA, Williams JD. Isolation, culture and characterization of human peritoneal mesothelial cells. Kidney Int. 1990;37(6):1563-70.

18. Howard JM, Singh LM. Peritoneal fluid Ph after perforation of peptic ulcers: the myth of "acid-peritonitis". Arch Surg. 1963;87: 483-4.

19. Moretz WH, Erickson WG. Neutralization of hydrochloric acid in the peritoneal cavity. AMA Arch Surg. 1957;75(5):834-7.

20. Aguirre AR, Abensur H. Physiology of fluid and solute transport across the peritoneal membrane. J Bras Nefrol. 2014;36(1):74-9.

21. Solass W, Horvath P, Struller F, Konigsrainer I, Beckert S, Konigsrainer A, et al. Functional vascular anatomy of the peritoneum in health and disease. Pleura Peritoneum. 2016;1(3):14558.

22. Michailova KN, Usunoff KG. Serosal membranes (pleura, pericardium, peritoneum). Normal structure, development and experimental pathology. Adv Anat Embryol Cell Biol. 2006;183:i-vii, 1-144, back cover.

23. Gotloib L, Shustak A, Bar-Sella P, Eiali V. Heterogeneous density and ultrastructure of rabbit's peritoneal microvasculature. Int J Artif Organs. 1984;7(3):123-5.

24. Aune S. Transperitoneal exchange. II. Peritoneal blood flow estimated by hydrogen gas clearance. Scand J Gastroenterol. 1970;5(2):99-104.

25. Flessner MF. Transport of water solube solutes between the peritoneal cavity and the plasma in the rat [PhD Thesis]. Department of Chemical Engineering, University of Michigan, Ann Arbor. 1981.

26. Grzegorzewska AE, Moore HL, Nolph KD, Ghen TW. Ultrafiltration and effective peritoneal blood flow during peritoneal dialysis in the rat. Kidney Int. 1991;39(4):608-17.

27. Rippe B, Rosengren BI, Venturoli D. The peritoneal microcirculation in peritoneal dialysis. Microcirculation. 2001;8(5):303-20.

28. Granger DN, Ulrich M, Perry MA, Kvietys PR. Peritoneal dialysis solutions and feline splanchnic blood flow. Clin Exp Pharmacol Physiol. 1984;11(5):473-81.

29. Lukas G, Brindle SD, Greengard P. The route of absorption of intraperitoneally administered compounds. J Pharmacol Exp Ther. 1971;178(3):562-4.

30. Granger HJ. Role of the interstitial matrix and lymphatic pump in regulation of transcapillary fluid balance. Microvasc Res. 1979;18(2):209-16.

31. Fraser PA, Smaje LH, Verrinder A. Microvascular pressures and filtration coefficients in the cat mesentery. J Physiol. 1978;283: 439-56.

32. Olin T, Saldeen T. The lymphatic pathways from the peritoneal cavity: A Lymphangiographic study in the Rat. Cancer Res. 1964;24:1700-11.

33. Esperanca MJCDL. Peritoneal dialysis efficiency in relation to body weight. J Pediatr Surg. 1966;1(2):162-9.

34. Kuzlan M, Pawlaczyk K, Wieczorowska-Tobis K, Korybalska K, Breborowicz A, Oreopoulos DG. Peritoneal surface area and its permeability in rats. Perit Dial Int. 1997;17(3):295-300.

35. Zink J, Greenway CV. Control of ascites absorption in anesthetized cats: effects of intraperitoneal pressure, protein, and furosemide diuresis. Gastroenterology. 1977;73(5):1119-24.

36. Jacquet P, Vidal-Jove J, Zhu B, Sugarbaker P. Peritoneal carcinomatosis from gastrointestinal malignancy: natural history and new prospects for management. Acta Chir Belg. 1994;94(4):191-7.

37. Sugarbaker PH. Cytoreductive surgery and intraperitoneal chemotherapy with peritoneal spread of cystadenocarcinoma. Eur J Surg Suppl. 1991;561:75-82.

38. Fedorko ME, Hirsch JG, Fried B. Studies on transport of macromolecules and small particles across mesothelial cells of the mouse omentum. II. Kinetic features and metabolic requirements. Exp Cell Res. 1971;69(2):313-23. 
39. Williams R, White $\mathrm{H}$. The greater omentum: its applicability to cancer surgery and cancer therapy. Curr Probl Surg. 1986;23(11): 789-865.

40. Surbone A, Myers CE. Principles and practice of intraperitoneal therapy. Antibiot Chemother (1971). 1988;40:14-25.

41. Flessner MF, Dedrick RL, Schultz JS. Exchange of macromolecules between peritoneal cavity and plasma. Am J Phys. 1985;248(1 Pt 2):H15-25.

42. Mactier RA, Khanna R. Absorption of fluid and solutes from the peritoneal cavity. Theoretic and therapeutic implications and applications. ASAIO Trans. 1989;35(2):122-31.

43. Gross ML, Somani P, Ribner BS, Raeader R, Freimer EH, Higgins JT Jr. Ceftizoxime elimination kinetics in continuous ambulatory peritoneal dialysis. Clin Pharmacol Ther. 1983;34(5): 673-80.

44. Canal P, Plusquellec Y, Chatelut E, Bugat R, De Biasi J, Houin G. A pharmacokinetic model for intraperitoneal administration of drugs: application to teniposide in humans. J Pharm Sci. 1989;78(5):389-92.

45. Flessner MF. Peritoneal transport physiology: insights from basic research. J Am Soc Nephrol. 1991;2(2):122-35.

46. Chambers R, Zwiefach BW. Functional activity of the blood capillary bed, with special reference to visceral tissue. Ann N Y Acad Sci. 1946;46:683-94.

47. Guyton AV, Hall JE. Chapter 14: Overview of the circulation; medical physics of pressure, flow, and resistance. In: Guyton AV, Hall JE, editors. Textbook of medical physiology. 11th ed. Philadelphia: Elsevier; 2006.

48. Karnovsky MJ. The ultrastructural basis of capillary permeability studied with peroxidase as a tracer.J Cell Biol. 1967;35(1):213-36.

49. Bruns RR, Palade GE. Studies on blood capillaries. II. Transport of ferritin molecules across the wall of muscle capillaries. J Cell Biol. 1968;37(2):277-99.

50. Di Paolo N, Sacchi G. Anatomy and physiology of the peritoneal membrane. Contrib Nephrol. 1990;84:10-26.

51. Bajaj G, Yeo Y. Drug delivery Systems for Intraperitoneal Therapy. Pharm Res-Dordr. 2010;27(5):735-8.

52. Krediet RT, Zuyderhoudt FM, Boeschoten EW, Arisz L. Alterations in the peritoneal transport of water and solutes during peritonitis in continuous ambulatory peritoneal dialysis patients. Eur J Clin Investig. 1987;17(1):43-52.

53. Lockhart RD, Hamilton, G. F. and Fyfe, F. W. Anatomy of the Human Body. J B Lippincott Company, Philadelphia. 1960.

54. Romanes GJ. Cunningham's textbook of anatomy. London: Oxford University Press; 1964.

55. Torres IJ, Litterst CL, Guarino AM. Transport of model compounds across the peritoneal membrane in the rat. Pharmacology. 1978;17(6):330-40.

56. Allen L. On the penetrability of the lymphatics of the diaphragm. Anat Rec. 1956;124(4):639-57.

57. Flessner MF, Parker RJ, Sieber SM. Peritoneal lymphatic uptake of fibrinogen and erythrocytes in the rat. Am J Phys. 1983;244(1): H89-96.

58. Regoeczi E, Zaimi O, Chindemi PA, Charlwood PA. Absorption of plasma proteins from peritoneal cavity of normal rats. Am J Phys. 1989;256(4 Pt 1):E447-52.

59. Courtice FC, Steinbeck AW. The rate of absorption of heparinized plasma and of 0.9 p.c. $\mathrm{NaCl}$ from the peritoneal cavity of the rabbit and Guinea-pig. Aust J Exp Biol Med Sci. 1950;28(2):17 182.

60. Courtice FC, Steinbeck AW. The lymphatic drainage of plasma from the peritoneal cavity of the cat. Aust J Exp Biol Med Sci. 1950;28(2):161-9.

61. Courtice FC, Simmonds WJ. Physiological significance of lymph drainage of the serous cavities and lungs. Physiol Rev. 1954;34(3): 419-48.
62. Raybuck HE, Allen L, Harms WS. Absorption of serum from the peritoneal cavity. Am J Phys. 1960;199:1021-4.

63. Allen L. Vogt E. A mechanism of lymphatic absorption from serous cavity Am J Physiol. 1937;1 19:776-82.

64. Miller FN. The peritoneal microcirculation. Peritoneal Dialysis. 1981.

65. Abernethy NJ, Chin W, Hay JB, Rodela H, Oreopoulos D, Johnston MG. Lymphatic drainage of the peritoneal cavity in sheep. Am J Phys. 1991;260(3 Pt 2):F353-8.

66. Durk MR, Deshmukh G, Valle N, Ding X, Liederer BM, Liu X. Use of subcutaneous and Intraperitoneal administration methods to facilitate cassette dosing in microdialysis studies in rats. Drug Metab Dispos. 2018;46(7):964-9.

67. Deshmukh G, Sun K, Liederer BM, Ding X, Liu X. Use of cassette dosing to enhance the throughput of rat brain microdialysis studies. Drug Metab Dispos. 2015;43(7):1123-8.

68. Liu X, Van Natta K, Yeo H, Vilenski O, Weller PE, Worboys PD, et al. Unbound drug concentration in brain homogenate and cerebral spinal fluid at steady state as a surrogate for unbound concentration in brain interstitial fluid. Drug Metab Dispos. 2009;37(4):787-93.

69. Shimada T, Nomura M, Yokogawa K, Endo Y, Sasaki T, Miyamoto K, et al. Pharmacokinetic advantage of intraperitoneal injection of docetaxel in the treatment for peritoneal dissemination of cancer in mice. J Pharm Pharmacol. 2005;57(2):177-81.

70. Hu K, Cao S, Hu F, Feng J. Enhanced oral bioavailability of docetaxel by lecithin nanoparticles: preparation, in vitro, and in vivo evaluation. Int $J$ Nanomedicine. 2012;7:3537-45.

71. Nemes KB, Abermann M, Bojti E, Grezal G, Al-Behaisi S, Klebovich I. Oral, intraperitoneal and intravenous pharmacokinetics of deramciclane and its $\mathrm{N}$-desmethyl metabolite in the rat. J Pharm Pharmacol. 2000;52(1):47-51.

72. Kim C, Kim IH, Kim SI, Kim YS, Kang SH, Moon SH, et al. Comparison of the Intraperitoneal, Retroorbital and per Oral routes for F-18 FDG administration as effective alternatives to intravenous Administration in Mouse Tumor Models Using Small Animal PET/CT studies. Nucl Med Mol Imaging. 201 1;45(3):169-76.

73. Matzneller P, Kussmann M, Eberl S, Maier-Salamon A, Jager W, Bauer M, et al. Pharmacokinetics of the P-gp inhibitor Tariquidar in rats after intravenous, Oral, and Intraperitoneal administration. Eur J Drug Metab Pharmacokinet. 2018;43(5):599-606.

74. Rozewski DM, Herman SE, Towns WH 2nd, Mahoney E, Stefanovski MR, Shin JD, et al. Pharmacokinetics and tissue disposition of lenalidomide in mice. AAPS J. 2012;14(4):872-82.

75. Abu-Hijleh MF, Habbal OA, Moqattash ST. The role of the diaphragm in lymphatic absorption from the peritoneal cavity. J Anat. 1995; 186(Pt 3):453-67.

76. Sane R, Mittapalli RK, Elmquist WF. Development and evaluation of a novel microemulsion formulation of elacridar to improve its bioavailability. J Pharm Sci. 2013;102(4):1343-54.

77. Chang R, Al Maghribi A, Vanderpoel V, Vasilevko V, Cribbs $\mathrm{DH}$, Boado R, et al. Brain penetrating Bifunctional erythropoietin-transferrin receptor antibody fusion protein for Alzheimer's disease. Mol Pharm. 2018;15(11):4963-73.

78. Lee B, Clarke D, Al Ahmad A, Kahle M, Parham C, Auckland L, et al. Perlecan domain $\mathrm{V}$ is neuroprotective and proangiogenic following ischemic stroke in rodents. J Clin Invest. 2011;121(8): 3005-23.

79. Zhang B, Dai J, Wang H, Wei H, Zhao J, Guo Y, et al. Antiosteopontin monoclonal antibody prevents ovariectomy-induced osteoporosis in mice by promotion of osteoclast apoptosis. Biochem Biophys Res Commun. 2014;452(3):795-800.

80. Wangler NJ, Jayaraman S, Zhu R, Mechref Y, Abbruscato TJ, Bickel U, et al. Preparation and preliminary characterization of 
recombinant neurolysin for in vivo studies. J Biotechnol. 2016;234:105-15.

81. Sumbria RK, Zhou QH, Hui EK, Lu JZ, Boado RJ, Pardridge WM. Pharmacokinetics and brain uptake of an IgG-TNF decoy receptor fusion protein following intravenous, intraperitoneal, and subcutaneous administration in mice. Mol Pharm. 2013;10(4): 1425-31.

82. Statler PA, McPherson RJ, Bauer LA, Kellert BA, Juul SE. Pharmacokinetics of high-dose recombinant erythropoietin in plasma and brain of neonatal rats. Pediatr Res. 2007;61(6):671-5.

83. Veronese FM, Caliceti P, Pastorino A, Schiavon O, Sartore L, Banci L, et al. Preparation, physico-chemical and pharmacokinetic characterization of monomethoxypoly(ethylene glycol)-derivatized superoxide dismutase. J Control Release. 1989;10(1):145-54.

84. Parkes D, Jodka C, Smith P, Nayak S, Rinehart L, Gingerich R, et al. Pharmacokinetic actions of Exendin-4 in the Rat: comparison with glucagon-like Peptide-1. Drug Dev Res. 2001;53:260-7.

85. Jacobs CA, Beckmann MP, Mohler K, Maliszewski CR, Fanslow WC, Lynch DH. Pharmacokinetic parameters and biodistribution of soluble cytokine receptors. Int Rev Exp Pathol. 1993;34 Pt B: 123-135.

86. Barrett JS, Wagner JG, Fisher SJ, Wahl RL. Effect of intraperitoneal injection volume and antibody protein dose on the pharmacokinetics of intraperitoneally administered IgG2a kappa murine monoclonal antibody in the rat. Cancer Res. 1991;51(13):343444 .

87. Koizumi K, DeNardo GL, DeNardo SJ, Hays MT, Hines HH, Scheibe PO, et al. Multicompartmental analysis of the kinetics of radioiodinated monoclonal antibody in patients with cancer. J Nucl Med. 1986;27(8):1243-54.

88. Griffiths K, Binder U, McDowell W, Tommasi R, Frigerio M, Darby WG, et al. Half-life extension and non-human primate pharmacokinetic safety studies of i-body AD-114 targeting human CXCR4. MAbs. 2019;11(7):1331-40.

89. Fam CM, Eisenberg SP, Carlson SJ, Chlipala EA, Cox GN, Rosendahl MS. PEGylation improves the pharmacokinetic properties and ability of interferon gamma to inhibit growth of a human tumor xenograft in athymic mice. J Interf Cytokine Res. 2014;34(10):759-68.

90. Goldenberg DM, Rossi EA, Stein R, Cardillo TM, Czuczman MS, Hernandez-Ilizaliturri FJ, et al. Properties and structurefunction relationships of veltuzumab (hA20), a humanized antiCD20 monoclonal antibody. Blood. 2009;113(5):1062-70.

91. Shi Q Kuether EL, Schroeder JA, Fahs SA, Montgomery RR. Intravascular recovery of VWF and FVIII following intraperitoneal injection and differences from intravenous and subcutaneous injection in mice. Haemophilia. 2012;18(4):639-46.

92. Gerrard AJ, Austen DE, Brownlee GG. Subcutaneous injection of factor IX for the treatment of haemophilia B. Br J Haematol. 1992;81(4):610-3.

93. Claassen V. Chap: 5 - Intraperitoneal drug administration; 1994.

94. Cardenas PA, Kratz JM, Hernandez A, Costa GM, Ospina LF, Baena Y, Simoes CMO, Jimenez-Kairuz A, Aragon M. In vitro intestinal permeability studies, pharmacokinetics and tissue distribution of 6-methylcoumarin after oral and intraperitoneal administration in Wistar rats. Braz J Pharm Sci. 2017;53(1).
95. Sane R, Agarwal S, Elmquist WF. Brain distribution and bioavailability of elacridar after different routes of administration in the mouse. Drug Metab Dispos. 2012;40(8):1612-9.

96. Sofia RD, Kubena RK, Barry H 3rd. Comparison of four vehicles for intraperitoneal administration of -tetrahydrocannabinol. J Pharm Pharmacol. 1971;23(11):889-91.

97. Sofia RD, Kubena RK, Barry H 3rd. Comparison among four vehicles and four routes for administering 89 -tetrahydrocannabinol. J Pharm Pharmacol. 1974;63(6):939-41.

98. Ritschel WA, Siegel EG, Ring PE. Biopharmaceutical factors influencing LD50. I Viscosity Arzneimittelforschung. 1974;24(6): 907-10.

99. Sigfridsson K, Lundqvist A, Strimfors M. Evaluation of exposure properties after injection of nanosuspensions and microsuspenions into the intraperitoneal space in rats. Drug Dev Ind Pharm. 2013;39(11):1832-9.

100. Sigfridsson K, Lundqvist AJ, Strimfors M. Particle size reduction and pharmacokinetic evaluation of a poorly soluble acid and a poorly soluble base during early development. Drug Dev Ind Pharm. 2011;37(3):243-51.

101. Sigfridsson K, Lundqvist A, Strimfors M. Subcutaneous administration of nano- and microsuspensions of poorly soluble compounds to rats. Drug Dev Ind Pharm. 2014;40(4): $511-8$.

102. Dimer FA, Pigatto MC, Boque CA, Pase CS, Roversi K, Pohlmann AR, et al. Nanoencapsulation improves relative bioavailability and antipsychotic effect of olanzapine in rats. $\mathrm{J}$ Biomed Nanotechnol. 2015;11(8):1482-93.

103. Badran MM, Alomrani AH, Harisa GI, Ashour AE, Kumar A, Yassin AE. Novel docetaxel chitosan-coated PLGA/PCL nanoparticles with magnified cytotoxicity and bioavailability. Biomed Pharmacother. 2018;106:1461-8.

104. Ragelle H, Crauste-Manciet S, Seguin J, Brossard D, Scherman D, Arnaud P, et al. Nanoemulsion formulation of fisetin improves bioavailability and antitumour activity in mice. Int $\mathrm{J}$ Pharm. 2012;427(2):452-9.

105. Ye M, Wysocki J, Gonzalez-Pacheco FR, Salem M, Evora K, Garcia-Halpin L, et al. Murine recombinant angiotensinconverting enzyme 2: effect on angiotensin II-dependent hypertension and distinctive angiotensin-converting enzyme 2 inhibitor characteristics on rodent and human angiotensinconverting enzyme 2. Hypertension. 2012;60(3):730-40.

106. Gotloib L, Wajsbrot V, Shostak A. A short review of experimental peritoneal sclerosis: from mice to men. Int J Artif Organs. 2005;28(2):97-104.

107. Micossi P, Cristallo M, Librenti MC, Petrella G, Galimberti G, Melandri M, et al. Free-insulin profiles after intraperitoneal, intramuscular, and subcutaneous insulin administration. Diabetes Care. 1986;9(6):575-8.

108. Black MC. Routes of administration for chemical agents. The laboratory fish London (UK): Academic Press. 2000.

109. Lewis REK, A. L.; Bell R. E. Error of intraperitoneal injections in rats. Lab Anim Care. 1966;16:505-9.

110. Bredberg E, Lennernas H, Paalzow L. Pharmacokinetics of levodopa and carbidopa in rats following different routes of administration. Pharm Res. 1994;1 1(4):549-55. 
111. Esquis P, Consolo D, Magnin G, Pointaire P, Moretto P, Ynsa MD, et al. High intra-abdominal pressure enhances the penetration and antitumor effect of intraperitoneal cisplatin on experimental peritoneal carcinomatosis. Ann Surg. 2006;244(1):106-12.

112. Bendavid Y, Leblond FA, Dube P. A study of the effect of temperature on the pharmacokinetic profile of raltitrexed administered by intraperitoneal route in the rat. Med Sci Monit. 2005;11(1):BR1-5.

113. Jacquet P, Averbach A, Stuart OA, Chang D, Sugarbaker PH. Hyperthermic intraperitoneal doxorubicin: pharmacokinetics, metabolism, and tissue distribution in a rat model. Cancer Chemother Pharmacol. 1998;41(2):147-54.

114. Sharp PELR, M. C. The laboratory rat. Boca Raton (FL): CRC Press LLC; 1997.

115. Pekow CB, V. Common nonsurgical techniques and procedures. Handbook of laboratory animal science: Boca Raton (FL): GRC Press. 2003;2(2nd ed):351-391.

116. Wolfensohn SE, Lloyd MH. Aleutian disease in laboratory ferrets. Vet Rec. 1994;134(4):100.
117. Woodard G. In methods of animal experimentation. Academic Press, New York. 1965;1:343-59.

118. De Marco TJ, Levine RR. Role of the lymphatics in the intestinal absorption and distribution of drugs. J Pharmacol Exp Ther. 1969;169(1):142-51.

119. Davis JN, Courtney CL, Superak H, Taylor DK. Behavioral, clinical and pathological effects of multiple daily intraperitoneal injections on female mice. Lab Anim (NY). 2014;43(4):131-9.

120. Gad SC, Spainhour CB, Shoemake C, Pallman DR, StrickerKrongrad A, Downing PA, et al. Tolerable levels of nonclinical vehicles and formulations used in studies by multiple routes in multiple species with notes on methods to improve utility. Int J Toxicol. 2016;35(2):95-178.

121. Al-Dewachi HS, Sangal BC, Zakaria MA. Synovial sarcoma of the abdominal wall: a case report and study of its fine structure. J Surg Oncol. 1981;18(4):335-44.

Publisher's Note Springer Nature remains neutral with regard to jurisdictional claims in published maps and institutional affiliations. 